\title{
Non-destructive estimates of soil carbonic anhydrase activity and associated soil water oxygen isotope composition
}

\author{
Sam P. Jones, Jérôme Ogée, Joana Sauze, Steven Wohl, Noelia Saavedra, Noelia Fernández-Prado, Juliette Maire, \\ Thomas Launois, Alexandre Bosc, and Lisa Wingate
}

INRA, UMR ISPA, 33140, Villenave d'Ornon, France

Correspondence: Sam P. Jones (samuel.jones@inra.fr)

Received: 23 July 2017 - Discussion started: 8 August 2017

Revised: 29 October 2017 - Accepted: 7 November 2017 - Published: 15 December 2017

\begin{abstract}
The contribution of photosynthesis and soil respiration to net land-atmosphere carbon dioxide $\left(\mathrm{CO}_{2}\right)$ exchange can be estimated based on the differential influence of leaves and soils on budgets of the oxygen isotope composition $\left(\delta^{18} \mathrm{O}\right)$ of atmospheric $\mathrm{CO}_{2}$. To do so, the activity of carbonic anhydrases (CAs), a group of enzymes that catalyse the hydration of $\mathrm{CO}_{2}$ in soils and plants, needs to be understood. Measurements of soil CA activity typically involve the inversion of models describing the $\delta^{18} \mathrm{O}$ of $\mathrm{CO}_{2}$ fluxes to solve for the apparent, potentially catalysed, rate of $\mathrm{CO}_{2}$ hydration. This requires information about the $\delta^{18} \mathrm{O}$ of $\mathrm{CO}_{2}$ in isotopic equilibrium with soil water, typically obtained from destructive, depth-resolved sampling and extraction of soil water. In doing so, an assumption is made about the soil water pool that $\mathrm{CO}_{2}$ interacts with, which may bias estimates of CA activity if incorrect. Furthermore, this can represent a significant challenge in data collection given the potential for spatial and temporal variability in the $\delta^{18} \mathrm{O}$ of soil water and limited a priori information with respect to the appropriate sampling resolution and depth. We investigated whether we could circumvent this requirement by inferring the rate of $\mathrm{CO}_{2}$ hydration and the $\delta^{18} \mathrm{O}$ of soil water from the relationship between the $\delta^{18} \mathrm{O}$ of $\mathrm{CO}_{2}$ fluxes and the $\delta^{18} \mathrm{O}$ of $\mathrm{CO}_{2}$ at the soil surface measured at different ambient $\mathrm{CO}_{2}$ conditions. This approach was tested through laboratory incubations of air-dried soils that were re-wetted with three waters of different $\delta^{18} \mathrm{O}$. Gas exchange measurements were made on these soils to estimate the rate of hydration and the $\delta^{18} \mathrm{O}$ of soil water, followed by soil water extraction to allow for comparison. Estimated rates of $\mathrm{CO}_{2}$ hydration were 6.8-14.6 times greater than the theoretical uncatalysed rate of hydration, indicating that CA were active in these soils. Impor-
\end{abstract}

tantly, these estimates were not significantly different among water treatments, suggesting that this represents a robust approach to assay the activity of CA in soil. As expected, estimates of the $\delta^{18} \mathrm{O}$ of the soil water that equilibrates with $\mathrm{CO}_{2}$ varied in response to alteration to the $\delta^{18} \mathrm{O}$ of soil water. However, these estimates were consistently more negative than the composition of the soil water extracted by cryogenic vacuum distillation at the end of the gas measurements with differences of up to $-3.94 \%$ VSMOW-SLAP. These offsets suggest that, at least at lower water contents, $\mathrm{CO}_{2-}$ $\mathrm{H}_{2} \mathrm{O}$ isotope equilibration primarily occurs with water pools that are bound to particle surfaces and are depleted in ${ }^{18} \mathrm{O}$ compared to bulk soil water.

\section{Introduction}

Carbonic anhydrases (CAs) are a group of metalloenzymes, typically utilising either zinc (Hewett-Emmett and Tashian, 1996) or cadmium (Xu et al., 2008), which catalyse the reversible hydration of dissolved carbon dioxide $\left(\mathrm{CO}_{2}\right)$. Spread amongst at least five unrelated classes, these enzymes have been identified in eukarya, bacteria and archaea (Gilmour, 2010). Such convergent evolution among diverse groups of organisms suggests that CAs are fundamental to many life strategies (Smith et al., 1999). Indeed, these enzymes have been linked to a number of common and specialised biological processes, such as $\mathrm{CO}_{2}$ concentration mechanisms required to maintain photosynthesis in plants, algae and cyanobacteria (Badger, 2003; Badger and Price, 1994); calcification to limit calcium toxicity in bacteria (Banks et al., 2010; $\mathrm{Li}$ et al., 2005b); maintenance of required $\mathrm{CO}_{2}$ 
and bicarbonate levels for metabolic activity in both bacteria (Merlin et al., 2003) and fungi (Kaur et al., 2009) growing under $\mathrm{CO}_{2}$ limited conditions; and metabolic flexibility in methanogenic archaea (Smith and Ferry, 2000). However, despite evidence of CA activity in soils, the variability and drivers of their expression by soil communities is poorly understood (Li et al., 2005a; Seibt et al., 2006; Wingate et al., 2009, 2008).

This knowledge gap is of particular importance as soil CA activity can considerably alter the oxygen isotope composition $\left(\delta^{18} \mathrm{O}\right)$ of atmospheric $\mathrm{CO}_{2}$ (Stern et al., 2001; Tans, 1998; Wingate et al., 2009). The presence of CA in soils and leaves influences the $\delta^{18} \mathrm{O}$ of atmospheric $\mathrm{CO}_{2}$ as oxygen isotopes are exchanged between $\mathrm{CO}_{2}$ and water during CA-catalysed hydration (Mills and Urey, 1940; Uchikawa and Zeebe, 2012). The $\delta^{18} \mathrm{O}$ of soil water $\left(\delta_{\text {sw }}\right)$ and leaf water pools are typically distinct because of differences in pool sizes and evaporation rates, and these different signals are transferred to dissolved $\mathrm{CO}_{2}$ molecules (Farquhar et al., 1993; Francey and Tans, 1987; Stern et al., 2001). This leads to contrasted $\delta^{18} \mathrm{O}$ signatures of soil-atmosphere $\left(\delta_{\mathrm{R}}\right)$ and leaf-atmosphere $\mathrm{CO}_{2}$ exchange that can be used to partition the contribution of photosynthesis and soil respiration, the largest gross fluxes in the contemporary atmospheric carbon cycle (Ciais et al., 2013), to the net atmospheric $\mathrm{CO}_{2}$ budget (Welp et al., 2011; Yakir and Wang, 1996). Whilst the extent to which the $\delta^{18} \mathrm{O}$ of $\mathrm{CO}_{2}$ interacting with leaves approaches equilibrium with leaf water pools has been considered (Gillon and Yakir, 2001), the degree to which the catalysis of $\mathrm{CO}_{2}$ hydration by CA in soils influences $\delta_{\mathrm{R}}$ is less well understood (Wingate et al., 2009). As such, appropriately modelling budgets of the $\delta^{18} \mathrm{O}$ of atmospheric $\mathrm{CO}_{2}$ relies on improving our knowledge of soil CA activity. In this respect, a better understanding of soil CA activity not only represents a frontier in soil ecology but also in understanding interactions between soil hydrological and carbon cycles, as well as ecosystem function within the carbon cycle on much larger scales.

A number of methods have been developed to estimate CA activity. Conventionally, assays have expressed activity by comparing the time required to achieve a set $\mathrm{pH}$ change in a $\mathrm{CO}_{2}$-saturated buffer solution in the presence and absence of CA-containing extracts (Wilbur and Anderson, 1948). Whilst this approach has been applied to soils ( $\mathrm{Li}$ et al., 2005a), the requirement to work with enzyme extractions at low temperatures implies that activity is being estimated under extremely disturbed conditions. Less disruptive isotope labelling techniques, which estimate the rate of hydration and thus CA activity based on the loss of the label from an $\delta^{18} \mathrm{O}$ enriched $\mathrm{CO}_{2}$ source (Mills and Urey, 1940; Tu et al., 1978), have also been applied to studies of aquatic algae (Hopkinson et al., 2013). Similarly, soil studies have focused on inverting models that describe $\delta_{\mathrm{R}}$ (Miller et al., 1999; Tans, 1998) to assay CA activity under realistic conditions from natural abundance gas flux measurements (Kapiluto et al., 2007;
Seibt et al., 2006; Wingate et al., 2008). Following Tans (1998) for a semi-infinite soil column with constant conditions throughout the depth profile, $\delta_{\mathrm{R}}(\%$ Vienna Pee Dee Belemnite $\mathrm{CO}_{2} ; \mathrm{VPDB}_{\mathrm{g}}$ ) at steady state can be described as follows (see also Wingate et al., 2010):

$\delta_{\mathrm{R}}=-\frac{v_{\text {inv }} C_{\mathrm{a}}}{F_{\mathrm{R}}} \delta_{\mathrm{a}}+\frac{v_{\text {inv }} C_{\mathrm{a}}}{F_{\mathrm{R}}} \delta_{\mathrm{eq}}+\delta_{\mathrm{eq}}-a$,

where $\delta_{\text {eq }}\left(\% \circ \mathrm{VPDB}_{\mathrm{g}}\right)$ is the $\delta^{18} \mathrm{O}$ of $\mathrm{CO}_{2}$ in isotopic equilibrium with soil water, $a(8.8 \%)$ is the isotopic fractionation associated with the diffusion of ${ }^{12} \mathrm{C}^{16} \mathrm{O}^{18} \mathrm{O}$ in still air, $v_{\text {inv }}\left(\mathrm{m} \mathrm{s}^{-1}\right)$ is the so-called piston or invasion velocity of $\mathrm{CO}_{2}, C_{\mathrm{a}}\left(\mu \mathrm{mol} \mathrm{m}{ }^{-3}\right)$ is the concentration of $\mathrm{CO}_{2}$ in the air at the soil-air interface, $F_{\mathrm{R}}\left(\mu \mathrm{mol} \mathrm{m}{ }^{-2} \mathrm{~s}^{-1}\right)$ is the net soilatmosphere $\mathrm{CO}_{2}$ flux and $\delta_{\mathrm{a}}(\%$ VPDB $)$ is the $\delta^{18} \mathrm{O}$ of $\mathrm{CO}_{2}$ at the soil-air interface. The rate of ${ }^{18} \mathrm{O}$ exchange between $\mathrm{CO}_{2}$ and soil water $\left(k_{\text {iso }}, \mathrm{s}^{-1}\right)$ can be deduced from $v_{\text {inv }}$ as follows:

$k_{\text {iso }}=\frac{v_{\text {inv }}^{2}}{B \theta_{\mathrm{w}} \kappa \phi_{\mathrm{a}} D}$,

where $B\left(\mathrm{~m}^{3} \mathrm{~m}^{-3}\right)$ is the solubility coefficient for $\mathrm{CO}_{2}$ in water, $\theta_{\mathrm{w}}\left(\mathrm{m}^{3} \mathrm{~m}^{-3}\right)$ is the volumetric soil water content, $\kappa$ is the tortuosity of the soil pore network, $\phi_{\mathrm{a}}$ is the soil airfilled porosity and $D\left(\mathrm{~m}^{2} \mathrm{~s}^{-1}\right)$ is the molecular diffusivity of ${ }^{12} \mathrm{C}^{16} \mathrm{O}^{18} \mathrm{O}$ in air. The activity of $\mathrm{CA}$ is then estimated from $k_{\text {iso }}$ using rate constants (Mills and Urey, 1940; Uchikawa and Zeebe, 2012), either as the equivalent CA concentration required to achieve the observed $k_{\text {iso }}$ assuming known enzymatic parameters (Ogée et al., 2016; Uchikawa and Zeebe, 2012) or as the unitless enhancement factor between $k_{\text {iso }}$ and the theoretical uncatalysed rate of $\mathrm{CO}_{2}-\mathrm{H}_{2} \mathrm{O}$ isotopic exchange (Seibt et al., 2006; Wingate et al., 2009, 2008). In the first instance, deducing a CA concentration is hampered by the paucity of information regarding the variability of CA kinetic parameters on the bulk soil scale (Ogée et al., 2016) as communities of fungi, algae, bacteria and archaea are likely to express a mixture of $\alpha, \beta$ and $\gamma$ CA classes (Gilmour, 2010; Smith and Ferry, 2000). The second approach has been used to describe temporal variations in CA activity (Seibt et al., 2006; Wingate et al., 2010, 2008), but its meaning is not always intuitive when applied across soil types, as the uncatalysed rate of exchange is $\mathrm{pH}$ dependent (Uchikawa and Zeebe, 2012). This aside, solving Eq. (1) also requires $\delta_{\text {eq }}$ to be determined from depth-resolved knowledge about $\delta_{\mathrm{sw}}$ (Wingate et al., 2009). In practice, $\delta_{\text {sw }}$ has been assumed to be relatively constant over short periods and either extrapolated from proximal sampling (Seibt et al., 2006; Wingate et al., 2009, 2008) or set by irrigating dried soils with water of known isotopic composition (Kapiluto et al., 2007). Over longer periods, the development of $\delta_{\mathrm{sw}}$ vertical profiles has also been estimated using soil water isotope transport models forced by meteorological data (Wingate et al., 2010). The appropriate value for $\delta_{\text {eq }}$ is then conceptually related 
to the shallowest depth at which respired or atmospheric $\mathrm{CO}_{2}$ has sufficient time to fully equilibrate with soil water (Miller et al., 1999; Wingate et al., 2009). For example, Wingate et al. (2009) estimate this depth as the soil depth below which ${ }^{12} \mathrm{C}^{16} \mathrm{O}^{18} \mathrm{O}$ molecules would take more than 4 times longer to diffuse out of the soil than it would take them to re-equilibrate with soil water. However, whilst use of this setting point is a convenient approximation in field settings (Wingate et al., 2009, 2010), some degree of exchange still occurs above this depth (Kapiluto et al., 2007). Given the need to make an assumption about the soil water pool with which $\mathrm{CO}_{2}$ is interacting, the potential for spatial and temporal variability of $\delta_{\mathrm{sw}}$, and limited a priori information with respect to appropriate sampling resolution and depth (Miller et al., 1999; Riley, 2005), approaches allowing CA activity to be estimated in the absence of this information are desirable.

Here we test whether soil CA activity can be reasonably estimated in the absence of independent information about $\delta_{\text {sw }}$ and investigate assumptions about soil $\mathrm{CO}_{2}-\mathrm{H}_{2} \mathrm{O}$ isotope equilibration. To do so we apply a novel approach to obtain solutions for $v_{\text {inv }}$ and $\delta_{\text {eq }}$, as a function of the response of $\delta_{\mathrm{R}}$ to variations in $\delta_{\mathrm{a}}$, from gas flux measurements. Equation (1) describes a linear relationship of the form $\delta_{\mathrm{R}}=m \delta_{\mathrm{a}}+c$, where the slope, $m$, is $v_{\mathrm{inv}} C_{\mathrm{a}} / F_{\mathrm{R}}$ and the intercept, $c$, is $v_{\text {inv }} C_{\mathrm{a}} / F_{\mathrm{R}} \delta_{\mathrm{eq}}+\delta_{\mathrm{eq}}-a$. If $C_{\mathrm{a}}$ and $F_{\mathrm{R}}$ are held constant, $v_{\text {inv }}$ and $\delta_{\text {eq }}$ can be estimated from a linear regression between $\delta_{\mathrm{R}}$ and $\delta_{\mathrm{a}}$ :

$v_{\mathrm{inv}}=\frac{-m}{C_{\mathrm{a}} / F_{\mathrm{R}}}$

$\delta_{\mathrm{eq}}=\frac{c+a}{1-m}$.

To test this approach, we conducted laboratory incubations using air-dried soils that were irrigated with one of three different waters that differed in terms of their $\delta^{18} \mathrm{O}\left(\delta_{\mathrm{iw}}\right.$, low, $\delta_{\text {iw, med }}$ or $\left.\delta_{\text {iw, high }}\right)$. The gas fluxes from these incubations were then sequentially measured under three different inlet conditions that varied in terms of the $\delta^{18} \mathrm{O}$ of $\mathrm{CO}_{2}\left(\delta_{\mathrm{b}}\right.$, low, $\delta_{\mathrm{b} \text {, med }}$ and $\delta_{\mathrm{b}, \text { high }}$ ) but not in terms of total $\mathrm{CO}_{2}$ concentration $\left(C_{\mathrm{b}}\right)$. Following gas measurements, water was cryogenically extracted from the incubated soils and its isotopic composition determined $\left(\delta_{\mathrm{sw}, \mathrm{ce}}\right)$ to allow for comparison with that estimated to be in equilibrium with $\mathrm{CO}_{2}$ from the gas flux measurements $\left(\delta_{\mathrm{sw}}\right.$, eq $)$. We specifically aimed to $(1)$ confirm the suitability of this approach by testing whether $\delta_{\mathrm{R}}$ and $\delta_{\mathrm{a}}$ are linearly related in an experimental context, (2) compare estimates of $\delta_{\mathrm{sw} \text {, eq }}$ determined from the gas flux measurements with $\delta_{\mathrm{sw}}$, ce measured for the extracted bulk soil water, and (3) compare the sensitivity of $k_{\text {iso }}$ estimates to variations in $\delta_{\mathrm{sw}}$.

\section{Materials and methods}

\subsection{Soil sampling and incubation preparation}

Soil was collected in April 2016 from Le Bray, a Pinus pinaster plantation in the southwest of France which has predominately sandy soil $(87.4 \%$ coarse sand, $6.2 \%$ fine sand, $2.7 \%$ silt and $3.7 \%$ clay), $3 \%$ organic carbon and a waterholding capacity of $0.27 \mathrm{~g} \mathrm{~g}^{-1}$ (Ogée et al., 2004; Wingate et al., 2010). After the removal of the under-story and the litter layer, consisting of living and dead Molinia caerulea tussocks, pine needles, pine cones and wood fragments, about $6 \mathrm{~kg}$ of soil was collected from the superficial $10 \mathrm{~cm}$ at four locations spaced $5 \mathrm{~m}$ apart. This material was mixed and passed through a $4 \mathrm{~mm}$ sieve to remove any large debris. Three sub-samples of the sieved soil were taken to determine the $\mathrm{pH}$, water content and $\delta_{\mathrm{sw}}$, ce of the fresh, sieved soil. The soil was air-dried for approximately 2 weeks before being stored in a closed box containing desiccant until the incubations were conducted between mid-June and mid-August 2016. Approximately $400 \mathrm{~g}$ of soil was used to determine the $\delta_{\text {sw, ce }}$ of any residual soil water, and six sub-samples were taken to determine $\mathrm{pH}$ after drying.

A total of 18 incubations were conducted with 6 replicates for each level of the irrigation water treatment. Each incubation was prepared by placing about $430 \mathrm{~g}$ of air-dried soil in a plastic ziplock bag. Approximately $30 \mathrm{~g}$ of soil was removed to determine the residual water content, and the remaining $400 \mathrm{~g}$ were re-wetted inside the bag with $40 \mathrm{~mL}$ of $\delta_{\text {iw, low }}, \delta_{\text {iw, med }}$ or $\delta_{\text {iw, high irrigation water. The bag was }}$ closed and gently mixed by hand, and $300 \mathrm{~g}$ of wet soil was then placed into a threaded polytetrafluoroethylene chamber with a height of $11.6 \mathrm{~cm}$ and an internal diameter of $7.3 \mathrm{~cm}$. The chamber was closed with a screw-top polytetrafluoroethylene lid and shaken at $200 \mathrm{rpm}$ for $10 \mathrm{~min}$ on an orbital shaker. The remaining $100 \mathrm{~g}$ of wet soil in the bag was then sampled for determination of the re-wetted water content and the initial $\delta_{\text {sw, ce }}$. Following shaking, the chamber was opened, sharply tapped to encourage the soil to settle in a uniform manner and placed inside a humidifier designed to maintain the soil water content and composition prior to the gas exchange measurements. This consisted of a desiccator filled with $500 \mathrm{~mL}$ of the irrigation water through which ambient air was bubbled using a membrane pump. The humidifier was wrapped in reflective foil and kept in a temperature-controlled room at $21^{\circ} \mathrm{C}$. Relative humidity and temperature inside the humidifier were monitored using a small combined sensor and data-logger (Hydrochron, iButtonLink, LLC., USA).

Typically, preparation and pre-incubation of the soils for each level of the water treatment spanned 3 days. Three chambers, staggered at $2 \mathrm{~h}$ intervals, were prepared on each of the first 2 days. The water used to re-wet the soil and initially fill the humidifier was sampled at the start of each day to characterise the isotopic composition of $\delta_{\mathrm{iw}}$, low,$\delta_{\mathrm{iw} \text {, med }}$ 
and $\delta_{\mathrm{iw}}$, high. The water in the humidifier was sampled once on day 2 and twice on day 3 to track any change in its isotopic composition over the course of the pre-incubation (not shown). Each chamber was pre-incubated for $24 \mathrm{~h}$ and then removed from the humidifier, weighed to determine water loss and finally connected to the gas exchange system. Following gas exchange measurements, the chamber was immediately removed and re-weighed to determine water loss over the measurement period. The depth of the soil $\left(z_{\max }\right)$ inside the chamber was then measured at four points using a digital calliper, and $1 \mathrm{~cm}$ thick horizons, from 0 to $5 \mathrm{~cm}$ depth, were removed and split for determination of depth-resolved water content and $\delta_{\text {sw, ce }}$.

Gravimetric water content was determined from weight change after oven drying at $105^{\circ} \mathrm{C}$ for $24 \mathrm{~h}$. Soil $\mathrm{pH}$ was determined from a soil-to-water slurry of $1: 5$ and measured in the supernatant after $2 \mathrm{~h}$. Soil bulk density was calculated from the initial gravimetric water content after re-wetting, the wet weight of the soil in the chamber and the volume of the soil in the chamber. Total porosity $\left(\phi_{\mathrm{t}}\right)$ was calculated from bulk density assuming a particle density of $2.65 \mathrm{~g} \mathrm{~cm}^{-3}$ (Linn and Doran, 1984). Volumetric water content $\left(\theta_{\mathrm{w}}\right)$ was calculated as the product of gravimetric water content and bulk density. The difference between $\phi_{\mathrm{t}}$ and $\theta_{\mathrm{w}}$ is $\phi_{\mathrm{a}}$.

\subsection{Soil water extraction and analysis}

Soil samples taken for determination of $\delta_{\text {sw, ce }}$ consisted of $20-25 \mathrm{~g}$ of material stored at $4{ }^{\circ} \mathrm{C}$ in $20 \mathrm{~mL}$ glass vials with positive insert screw-top caps. Water samples were extracted from these soils using a cryogenic vacuum distillation system based on the design and methodology described by Orlowski et al. (2013). In brief, the system consists of six branches each equipped with four extraction vessels, a Pirani vacuum gauge (APG100-XLC, Edwards, UK) and an isolation valve. The branches connect to a manifold equipped with a vacuum gauge, a vacuum release valve and a two-stage rotary vane vacuum pump (RV5, Edwards, UK). Extractions were prepared by placing about $20 \mathrm{~g}$ of soil, topped with oven-baked glass wool, into an extraction vessel. For each branch, extraction vessels were weighed and frozen in a bath of liquid nitrogen. After freezing, the manifold and branches were checked for leaks using the vacuum gauges and evacuated to a starting pressure of less than $0.3 \mathrm{~Pa}$. Extractions were initiated by isolating a branch, transferring the liquid nitrogen bath to a U-shaped water trap and the sample vessels to a water bath initially at room temperature. Extractions lasted for $180 \mathrm{~min}$ and the water bath was set to $80^{\circ} \mathrm{C}$ after $60 \mathrm{~min}$. Following extraction, the water traps were removed, the ends sealed with parafilm and the collected ice allowed to thaw before being weighed. The extracted waters were transferred to $5 \mathrm{~mL}$ glass vials with positive insert screw-top caps and stored at $4^{\circ} \mathrm{C}$. Extraction vessels and empty water traps were ovendried and re-weighed to determine extraction efficiency.
The accuracy of cryogenic vacuum distillation techniques has been questioned as the $\delta^{18} \mathrm{O}$ of extracted waters tends to be depleted in ${ }^{18} \mathrm{O}$ relative to the irrigation water when oven-dried soils that have been re-wetted are considered (Orlowski et al., 2016a; Sprenger et al., 2015). The extent of this depletion depends on soil properties. To quantify biases associated with our methodology and the soil studied, two tests were conducted where six $20 \mathrm{~g}$ soil samples were rewetted to a gravimetric water content of about $0.1 \mathrm{~g} \mathrm{~g}^{-1}$ with water that had a $\delta^{18} \mathrm{O}$ of $-4.84 \pm 0.06 \%$ Vienna Standard Mean Ocean Water-Standard Light Antarctic Precipitation (VSMOW-SLAP). In the first test, residual water was removed from air-dried soil by oven drying at $105^{\circ} \mathrm{C}$ for $24 \mathrm{~h}$ prior to re-wetting. In the second test, residual water was removed by cryogenic extraction following the above methodology prior to re-wetting. These soils were then treated as described for samples.

The $\delta^{18} \mathrm{O}$ of the irrigation waters, $\delta_{\mathrm{iw}, \text { low }}, \delta_{\mathrm{iw}, \text { med }}$ and $\delta_{\mathrm{iw}}$, high, and cryogenically extracted water samples, $\delta_{\mathrm{sw}, \mathrm{ce}}$, were measured on an off-axis integrated cavity optical spectrometer (TIWA-45EP, Los Gatos Research, USA) coupled to an auto-sampler (Berman et al., 2013). Prior to analysis, $1 \mathrm{~mL}$ of each water sample was pipetted into a $1.5 \mathrm{~mL}$ vial and capped with a pre-slit septa. An auto-sampler equipped with a $5 \mu \mathrm{L}$ syringe and a heated septum port (PAL LCxt, CTC Analytics AG, Switzerland) sequentially injected 8 aliquots of each sample into the analyser. The first three injections for each sample were discarded to avoid inter-sample memory effects (Lis et al., 2008), as were any injections flagged by the analyser's software (Berman et al., 2013). To avoid applying a linearity correction, the mean water density for a run was calculated and any injection with a water density more than $10^{15}$ molecules $\mathrm{cm}^{-3}$ away from the mean was rejected (Lis et al., 2008). The mean water density was then re-calculated and only injections within 3 standard deviations were retained. A raw mean $\delta^{18} \mathrm{O}$ was calculated for all samples where three to five injections were retained. We accounted for analyser drift and report on the VSMOW-SLAP scale by including two working standards ( 10.31 and $0.62 \%$ VSMOW-SLAP) and a quality control sample ( $4.84 \pm 0.06 \%$ VSMOW-SLAP) between every five unknown samples.

\subsection{Incubation system and gas analysis}

Measurement of gas fluxes under the three different inlet conditions, $\delta_{\mathrm{b} \text {, low }}, \delta_{\mathrm{b} \text {, med }}$ and $\delta_{\mathrm{b}}$, high, was achieved using a gas supply manifold capable of delivering one of three gas mixtures to the inlet of the incubation system (Fig. 1). Briefly, the inlet to the incubation system was connected to a normally closed $2 / 2$ solenoid valve actuated by a microcontroller (Arduino Uno, Arduino LLC, Italy). One port of the valve was connected directly to a cylinder of compressed air $\left(\delta_{\mathrm{b}}\right.$, high $)$ with a total $\mathrm{CO}_{2}$ concentration and $\delta^{18} \mathrm{O}$ of $424.93 \pm 0.01 \mathrm{ppm}$ and $3.45 \pm 0.02 \% \mathrm{VPDB}_{\mathrm{g}}$ (NOAA Earth 


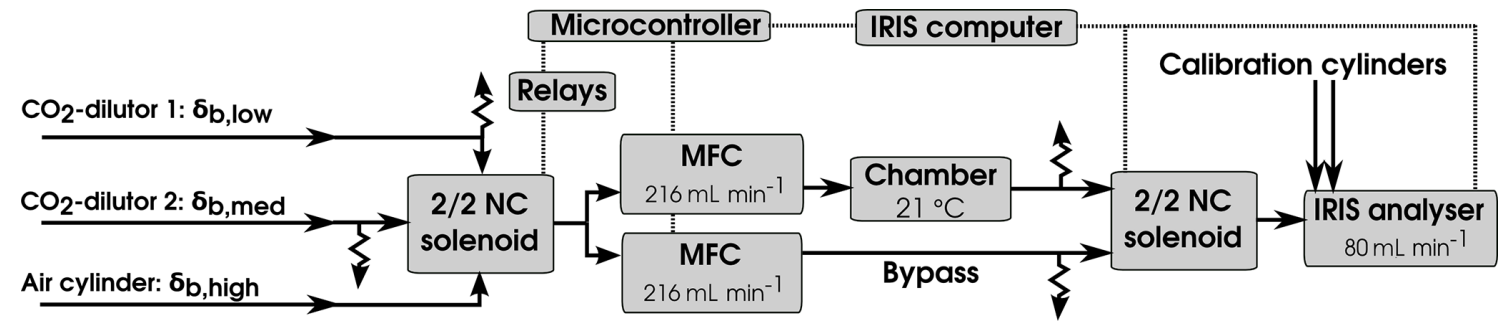

Figure 1. Schematic of the system used to make gas exchange measurements. Alternate measurements of the concentration and $\delta^{18} \mathrm{O}_{\text {of }} \mathrm{CO}_{2}$ in chamber $\left(\mathrm{C}_{\mathrm{a}}, \delta_{\mathrm{a}}\right)$ and bypass lines $\left(\mathrm{C}_{\mathrm{b}}, \delta_{\mathrm{b}}\right)$ are made under three inlet conditions $\left(\delta_{\mathrm{b}, \text { low }}, \delta_{\mathrm{b}, \text { med }}, \delta_{\mathrm{b}}\right.$, high $)$ that differ in terms of the $\delta^{18} \mathrm{O}$ of $\mathrm{CO}_{2}$.

System Research Laboratory, USA). The other ports were preceded by open splits and connected to continuous flows from two in-house gas dilution systems capable of providing a given concentration of $\mathrm{CO}_{2}$ by mixing pure $\mathrm{CO}_{2}$ from gas cylinders into $\mathrm{CO}_{2}$-free air generated by an air compressor (FM2 Atlas Copto, Nacka, Sweden) equipped with a scrubbing column (Ecodry K-MT6, Parker Hannifin, USA). The concentrations of the two gas dilutions were adjusted to match that of the cylinder containing $\delta_{\mathrm{b}}$, high, and contrasts in $\delta^{18} \mathrm{O}$ were achieved by using pure $\mathrm{CO}_{2}$ cylinders of different origins $\left(\delta_{\mathrm{b}, \text { med }}\right.$ and $\left.\delta_{\mathrm{b}, \text { low }}\right)$. Following the inlet of the incubation system, the gas stream was split into a chamber and bypass line that terminated at open splits in front of a normally closed 2/2 solenoid valve connected to the sample inlet of a $\mathrm{CO}_{2}$ isotope ratio infra-red spectrometer (DeltaRay IRIS, Thermo Fischer Scientific, Germany). The flow rate of each line was limited to $216 \mathrm{~mL} \mathrm{~min}^{-1}$ using two mass-flow controllers. The soil chamber was connected in-line at the middle of the chamber line and placed in a water bath at $21^{\circ} \mathrm{C}$.

Gas exchange measurements were made by alternately switching the valve to the sample inlet of the IRIS, allowing approximately $80 \mathrm{~mL} \mathrm{~min}^{-1}$ of the total flow to pass through the instrument, three times between bypass and chamber lines. The IRIS reports concentrations at $1 \mathrm{~Hz}$ for the three most abundant isotopologues of $\mathrm{CO}_{2}\left({ }^{12} \mathrm{C}^{16} \mathrm{O}^{16} \mathrm{O}\right.$, ${ }^{13} \mathrm{C}^{16} \mathrm{O}^{16} \mathrm{O}$ and ${ }^{12} \mathrm{C}^{18} \mathrm{O}^{16} \mathrm{O}$ ), allowing determination of the total concentration and isotopic composition of $\mathrm{CO}_{2}$ (Geldern et al., 2014; Rizzo et al., 2014). The stability of measurements of the total concentration and the $\delta^{18} \mathrm{O}$ of $\mathrm{CO}_{2}$ were assessed prior to the gas exchange measurements by analysing the contents of an air cylinder for $22.5 \mathrm{~h}$ (Fig. S1 in the Supplement) and subsequent computation of Allan variances (Carrio, 2015). A maximum precision of $0.01 \mathrm{ppm}$ for total $\mathrm{CO}_{2}$ and $0.05 \%$ VPDB $\mathrm{g}$ for $\delta^{18} \mathrm{O}$ was achieved after integrating over 172 and $144 \mathrm{~s}$, respectively. Given the profile of the Allan plot (Werle, 2010) and the $35 \mathrm{~s}$ residence time of the air in the instrument cell (Geldern et al., 2014), a measurement period of $120 \mathrm{~s}$ was used. The first $80 \mathrm{~s}$ of each measurement were discarded to minimise carry-over effects and the final $40 \mathrm{~s}$ were kept and averaged to provide a measurement mean and standard deviation. A 40 s integra- tion period corresponds to standard deviations for total $\mathrm{CO}_{2}$ and the $\delta^{18} \mathrm{O}$ of $\mathrm{CO}_{2}$ of $0.02 \mathrm{ppm}$ and $0.06 \%$ o $\mathrm{VPDB}_{\mathrm{g}}$, respectively. Averaged isotopologue concentrations were corrected by bracketing every three pairs of bypass and chamber line measurements with the measurement of two calibration cylinders (Deuste Steinger GmbH, Germany). The standard deviations for total $\mathrm{CO}_{2}$ and the $\delta^{18} \mathrm{O}$ of $\mathrm{CO}_{2}$ over $960 \mathrm{~s}$ (the interval between two calibration measurements) were $0.02 \mathrm{ppm}$ and $0.06 \%$ o $\mathrm{VPDB}_{\mathrm{g}}$, respectively.

The calibration cylinders contained mixtures of $\mathrm{CO}_{2}$ in synthetic air $\left(21 \% \mathrm{O}_{2}\right.$ and $0.93 \%$ Ar in a $\mathrm{N}_{2}$ balance $)$ that had been characterised for the total concentration, carbon isotope composition and $\delta^{18} \mathrm{O}$ of $\mathrm{CO}_{2}$ (Max Planck Institute for Biogeochemistry IsoLab, Germany). The total concentration, carbon isotope composition and $\delta^{18} \mathrm{O}$ of $\mathrm{CO}_{2}$ for each cylinder were, respectively, $380.26 \mathrm{ppm}$, $3.064 \%$ VPDB and $14.631 \% \circ \mathrm{VPDB}_{\mathrm{g}}$, and $481.62 \mathrm{ppm}$, $3.071 \%$ VPDB and $14.698 \%$ VPDB $_{\mathrm{g}}$. Concentrations of ${ }^{12} \mathrm{C}^{16} \mathrm{O}^{16} \mathrm{O},{ }^{13} \mathrm{C}^{16} \mathrm{O}^{16} \mathrm{O}$ and ${ }^{12} \mathrm{C}^{18} \mathrm{O}^{16} \mathrm{O}$ were calculated from these values following Wen et al. (2013). Measured averages for the calibration cylinders were linearly interpolated and correction coefficients calculated from two-point linear regressions between cylinders, allowing correction of sample isotopologue concentrations and calculation of total concentration and $\delta^{18} \mathrm{O}$ of $\mathrm{CO}_{2}$ (Bowling et al., 2003; Wen et al., 2013; Wingate et al., 2010). This calibration scheme was validated for our isotopic measurements by allowing $40 \mathrm{~L}$ of pure $\mathrm{CO}_{2}$ to equilibrate with $4 \mathrm{~L}$ of water in a $25 \mathrm{~L}$ barrel at $24{ }^{\circ} \mathrm{C}$. Approximately 3 months after filling, the $\delta^{18} \mathrm{O}$ of $\mathrm{CO}_{2}$ in the barrel head space, calibrated using the scheme described above, was measured in dilutions with concentrations ranging from 390 to $560 \mathrm{ppm}$. Following these measurements the water with which the $\mathrm{CO}_{2}$ had equilibrated with was sampled and its $\delta^{18} \mathrm{O}$ determined as described previously. Measurements of $\delta^{18} \mathrm{O}$ of $\mathrm{CO}_{2}$ were not significantly dependent on $\mathrm{CO}_{2}$ concentration over this range but the composition of the $\delta^{18} \mathrm{O}$ of $\mathrm{CO}_{2}$ was, on average, $0.31 \%$ more depleted than that of the water. To account for this offset between our gas and water measurements, a post-calibration correction of $+0.31 \%$ was applied to all bypass and chamber $\mathrm{CO}_{2}$ measurements. 
The net soil $\mathrm{CO}_{2}$ flux, $F_{\mathrm{R}}$, was calculated from the corrected values for each pair of calibrated bypass and chamber measurements as follows:

$F_{\mathrm{R}}=\frac{u}{A}\left(C_{\mathrm{a}}-C_{\mathrm{b}}\right)$,

where $u\left(\mathrm{~mol} \mathrm{~s}^{-1}\right)$ is the flow rate of dry air through the chamber line, $C_{\mathrm{a}}(\mathrm{ppm})$ is the $\mathrm{CO}_{2}$ concentration of the chamber line, $C_{\mathrm{b}}(\mathrm{ppm})$ is the $\mathrm{CO}_{2}$ concentration of the bypass line, and $A\left(\mathrm{~m}^{2}\right)$ is the surface area of the soil in the chamber. Similarly, the $\delta^{18} \mathrm{O}$ of soil-atmosphere $\mathrm{CO}_{2}$ exchange, $\delta_{\mathrm{R}}$, was calculated as follows:

$\delta_{\mathrm{R}}=\frac{\delta_{\mathrm{a}} C_{\mathrm{a}, 12}-\delta_{\mathrm{b}} C_{\mathrm{b}, 12}}{C_{\mathrm{a}, 12}-C_{\mathrm{b}, 12}}$,

where $\delta_{\mathrm{a}}$ and $\mathrm{C}_{\mathrm{a}, 12}(\mathrm{ppm})$ are, respectively, the $\delta^{18} \mathrm{O}$ of $\mathrm{CO}_{2}$ and concentration of ${ }^{12} \mathrm{C}^{16} \mathrm{O}^{16} \mathrm{O}$ in the chamber line and $\delta_{\mathrm{b}}$ and $\mathrm{C}_{\mathrm{b}, 12}(\mathrm{ppm})$ are the $\delta^{18} \mathrm{O}$ of $\mathrm{CO}_{2}$ and concentration of ${ }^{12} \mathrm{C}^{16} \mathrm{O}^{16} \mathrm{O}$ in the bypass line. To ensure steady-state conditions for measurements under the three different inlet conditions, a complete cycle where only the chamber line was measured was included to allow the chamber head-space and soil pore-space conditions to stabilise between transitions from atmospheric conditions at the start of the incubation and subsequent inlet conditions (Fig. 2). The order of the inlet conditions was varied between the 6 replicates of each level of the irrigation water treatment to avoid introducing a temporal measurement bias.

\subsection{Data processing}

All data processing and analysis was conducted in $\mathrm{R}$ version 3.3 (R Core Team, 2017). The slopes and intercepts of linear relationships between the $\delta^{18} \mathrm{O}$ of soil-atmosphere $\mathrm{CO}_{2}$ exchange, $\delta_{\mathrm{R}}$, and the $\delta^{18} \mathrm{O}$ of $\mathrm{CO}_{2}$ at the soil surface (taken here to be that of the chamber line), $\delta_{\mathrm{a}}$, were calculated from the measurements made under the three different inlet conditions for each of the incubations (Bates et al., 2015). Following Eq. (3a), the piston velocity of $\mathrm{CO}_{2}, v_{\text {inv }}$, was estimated using the slope of the linear regression, $m$, and the mean ratio of concentration of $\mathrm{CO}_{2}$ at the soil surface and net $\mathrm{CO}_{2}$ flux, $C_{\mathrm{a}} / F_{\mathrm{R}}$, for each incubation. As Eq. (3) is only strictly valid when there is a semi-infinite soil column (Tans, 1998), we adapted the equation to account for the influence of boundary conditions found at the bottom of the incubation vessel. The soil-depth-adjusted piston velocity ( $\left.\widetilde{v}_{\text {inv }}\right)$ was estimated by using $v_{\text {inv }}$ obtained from Eq. (3a) to iteratively satisfy the following:

$v_{\text {inv }}=\widetilde{v}_{\text {inv }} \tanh \left(\frac{\widetilde{v}_{\text {inv }} z_{\max }}{\kappa \phi_{\mathrm{a}} D}\right)$,

where $z_{\max }(\mathrm{m})$ is the total soil column depth. In doing so we adopted the formulation of Moldrup et al. (2003) for the tortuosity, $\kappa$, of repacked soils:

$\kappa=\frac{\phi_{\mathrm{a}}^{1.5}}{\phi_{\mathrm{t}}}$.
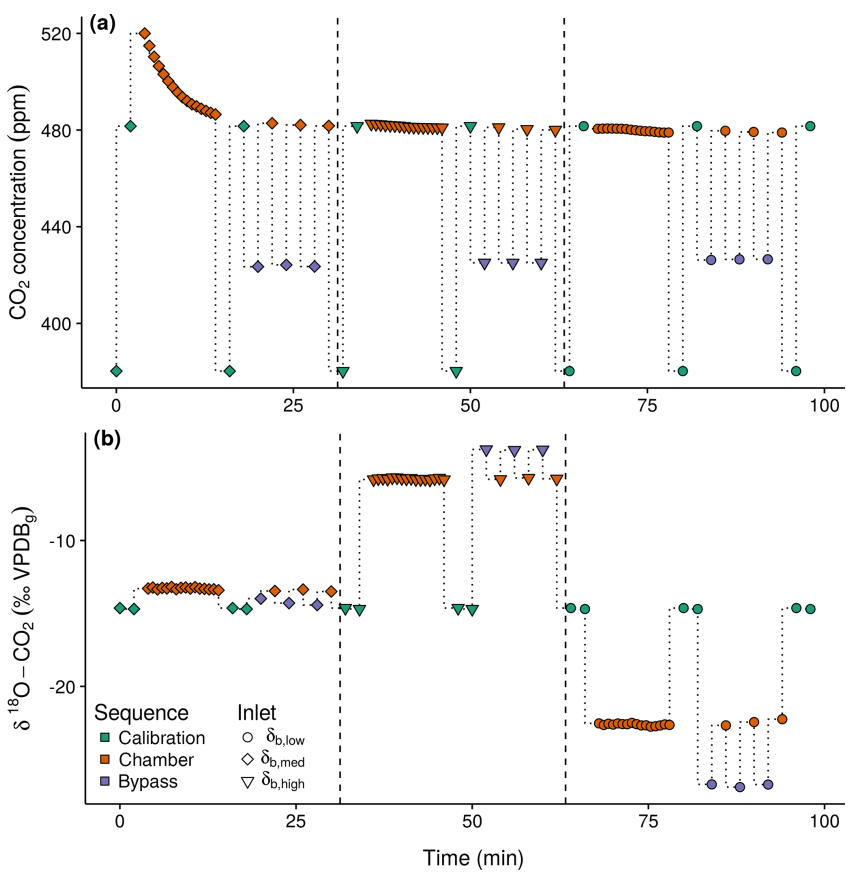

Figure 2. An example of the gas exchange measurement sequence, sequentially scanning calibration cylinders, the chamber line during a stabilisation period, calibration cylinders again and finally the chamber and bypass lines, for the three different $\delta^{18} \mathrm{O}$ of $\mathrm{CO}_{2}$ delivered to the inlet of the incubation system $\left(\delta_{\mathrm{b}}\right)$. In this case, the $\delta_{\mathrm{b}}$ inlet conditions, whose changes are indicated by the vertical dashed lines, started with $\delta_{\mathrm{b} \text {, med }}$ and ended with $\delta_{\mathrm{b} \text {, low }}$. Symbols represent the calibrated average values and the dotted line is provided as a visual aid and does not correspond to raw $1 \mathrm{~Hz}$ data; panel (a) shows total $\mathrm{CO}_{2}$ concentration and (b) shows $\delta^{18} \mathrm{O}$ of $\mathrm{CO}_{2}$.

Temperature-dependent $\mathrm{CO}_{2}$ solubility, $B$, was calculated using Weiss (1974) and the diffusivity of ${ }^{12} \mathrm{C}^{16} \mathrm{O}^{18} \mathrm{O}$ in air, $D$, was calculated according to Massman (1998) and Tans (1998):

$D=1.381 \times 10^{-5} \frac{T}{273.15}^{1.81}\left(1-\frac{a}{1000}\right)$,

where $T(\mathrm{~K})$ is soil temperature. Derived estimates of $\widetilde{v}_{\text {inv }}$ were then used to calculate the apparent rate of hydration, $k_{\text {iso }}$, by replacing $v_{\text {inv }}$ with $\widetilde{v}_{\text {inv }}$ in Eq. (2). The difference between the semi-infinite and finite-depth solutions are shown in Fig. S2 for different soil depths. For this soil type and water content, a soil depth of $>8 \mathrm{~cm}$ is necessary to be able to neglect the influence of boundary conditions found at the bottom of the incubation vessel.

Corrections for a finite soil depth had also to be applied to estimate the $\delta^{18} \mathrm{O}$ of $\mathrm{CO}_{2}$ in equilibrium with soil water, $\delta_{\text {eq }}$. For this, the soil-depth-adjusted isotopic fractionation associated with the diffusion of $\mathrm{CO}_{2}(\widetilde{a})$ was first calculated as follows:

$\tilde{a}=a\left(1-\frac{\kappa \phi_{\mathrm{a}} D}{\widetilde{v}_{\text {inv }} z_{\max }} \tanh \left(\frac{\widetilde{v}_{\text {inv }} z_{\max }}{\kappa \phi_{\mathrm{a}} D}\right)\right)$, 
Table 1. Soil properties by irrigation water treatment $\left(\delta_{\mathrm{iw}}\right)$. Means $(n=6)$ and standard deviations (in parentheses) for bulk density, soil depth $\left(z_{\max }\right)$, total porosity $\left(\phi_{\mathrm{t}}\right)$, volumetric soil water content $\left(\theta_{\mathrm{W}}\right)$ and tortuosity $(\kappa)$. Superscript letters following each mean and deviation indicate significant differences (one-way analysis of variance and Tukey's HSD, $p<0.01$ ) among $\delta_{\text {iw }}$ treatments.

\begin{tabular}{lccccc}
\hline Treatment & $\begin{array}{c}\text { Bulk density } \\
\left(\mathrm{g} \mathrm{cm}^{-3}\right)\end{array}$ & $\begin{array}{c}z_{\max } \\
(\mathrm{mm})\end{array}$ & $\phi_{\mathrm{t}}$ & $\theta_{\mathrm{w}}$ & $\kappa$ \\
\hline$\delta_{\text {iw, low }}$ & $1.06(0.03)^{\mathrm{a}}$ & $60.3(1.5)^{\mathrm{a}}$ & $0.599(0.010)^{\mathrm{a}}$ & $0.112(0.002)^{\mathrm{a}}$ & $0.57(0.01)^{\mathrm{a}}$ \\
$\delta_{\text {iw, med }}$ & $1.04(0.01)^{\mathrm{a}}$ & $61.5(0.8)^{\mathrm{a}}$ & $0.607(0.004)^{\mathrm{a}}$ & $0.110(0.002)^{\mathrm{a}}$ & $0.58(0.01)^{\mathrm{a}}$ \\
$\delta_{\text {iw, high }}$ & $1.06(0.03)^{\mathrm{a}}$ & $60.3(1.4)^{\mathrm{a}}$ & $0.599(0.009)^{\mathrm{a}}$ & $0.112(0.002)^{\mathrm{a}}$ & $0.57(0.01)^{\mathrm{a}}$ \\
\hline
\end{tabular}

where the full diffusional fractionation, $a$, was set to $8.8 \%$ o (Riley, 2005). Estimates of $\delta_{\text {eq }}$ were then obtained using the intercept, $c$, of the linear regression and by replacing the slope, $m$, with $-\widetilde{v}_{\text {inv }} C_{\mathrm{a}} / F_{\mathrm{R}}$ and $a$ with $\widetilde{a}$ in Eq. (3b). To allow for comparison with the $\delta^{18} \mathrm{O}$ of soil water determined following cryogenic extraction, $\delta_{\mathrm{sw}, \mathrm{ce}}$, derived estimates of $\delta_{\text {eq }}$ were converted to equivalent values of the $\delta^{18} \mathrm{O}$ of soil water in equilibrium with $\mathrm{CO}_{2}, \delta_{\mathrm{sw} \text {, eq }}$, based on the temperature-dependent equilibration fractionation between water and $\mathrm{CO}_{2}$ and the difference between the $\mathrm{VPDB}_{\mathrm{g}}$ and VSMOW-SLAP scales (Brenninkmeijer et al., 1983; Kapiluto et al., 2007; Wingate et al., 2010):

$\delta_{\mathrm{sw}, \mathrm{eq}}=\delta_{\mathrm{eq}}+0.2(T-297.15)$.

Treatment summaries are reported as mean and standard deviation unless stated otherwise. A total of 18 incubations were conducted on sub-samples of same homogenised soil. Six independently replicated incubations were conducted for each level $\left(\delta_{\mathrm{iw}, \text { low }}, \delta_{\mathrm{iw}, \text { med }}\right.$ and $\left.\delta_{\mathrm{iw}, \text { high }}\right)$ of the irrigation water treatment. Soil properties and model parameters were determined individually for each incubation as described above. Differences in soil properties and model parameters in response to the water treatment, with statistical significance reported at $p<0.01$, were tested through one-way analysis of variance with post hoc comparison by Tukey's HSD (Crawley, 2007; Mendiburu, 2016). To do so, a given property or parameter was taken as the dependent variable and water treatment as the categorical independent variable.

\section{Results}

\subsection{Soil properties}

The gravimetric water content and $\mathrm{pH}$ of freshly sampled, sieved soil were $0.207 \pm 0.005 \mathrm{~g} \mathrm{~g}^{-1}$ and $4.75 \pm 0.05$, respectively. The $\mathrm{pH}$ of the air-dried soil was $4.34 \pm 0.02$. Measured soil properties were not statistically different among water treatments. Following drying and storage, the gravimetric water content of air-dried soil measured during incubation preparation was $0.010 \pm 0.001 \mathrm{~g} \mathrm{~g}^{-1}$. After rewetting and mixing, the gravimetric water content of the soil placed into incubation chambers was $0.107 \pm 0.002 \mathrm{~g} \mathrm{~g}^{-1}$.
During the 24-hour pre-incubation $0.172 \pm 0.075 \mathrm{~g}$ of water evaporated and a further $0.361 \pm 0.050 \mathrm{~g}$ of water was subsequently lost over the course of the $96 \mathrm{~min}$ gas exchange measurement. Gravimetric water contents were $0.099 \pm 0.005 \mathrm{~g} \mathrm{~g}^{-1}$ at $0-1 \mathrm{~cm}, 0.105 \pm 0.003 \mathrm{~g} \mathrm{~g}^{-1}$ at $1-$ $2 \mathrm{~cm}, 0.106 \pm 0.003 \mathrm{~g} \mathrm{~g}^{-1}$ at $2-3 \mathrm{~cm}, 0.107 \pm 0.003 \mathrm{~g} \mathrm{~g}^{-1}$ at $3-4 \mathrm{~cm}$ and $0.107 \pm 0.002 \mathrm{~g} \mathrm{~g}^{-1}$ at $4-5 \mathrm{~cm}$. The other soil properties determined following gas exchange measurements are summarised by water treatment in Table 1 .

\subsection{Water composition}

The $\delta^{18} \mathrm{O}$ of soil water determined following cryogenic extraction, $\delta_{\mathrm{sw} \text {, ce }}$, of freshly sampled soil was $-3.63 \pm 0.10 \%$ o VSMOW-SLAP. After air drying and storage, the $\delta_{\mathrm{sw} \text {, ce }}$ of the residual water pool was $-6.69 \pm 0.01 \%$ VSMOWSLAP. Mean $\delta^{18} \mathrm{O}$ and standard errors for the $\delta_{\mathrm{iw}, \text { low }}$, $\delta_{\mathrm{iw}, \text { med }}$ and $\delta_{\mathrm{iw}, \text { high }}$ irrigation waters were, respectively, $-6.74 \pm 0.03,-3.69 \pm 0.03$ and $0.24 \pm 0.04 \%$ VSMOWSLAP. The addition of these waters to the air-dried soils used in the incubations resulted in initial $\delta_{\mathrm{sw}, \text { ce }}$ of $-7.03 \pm 0.34$, $-4.28 \pm 0.21$ and $-0.80 \pm 0.05 \%$ VSMOW-SLAP for the $\delta_{\mathrm{iw}, \text { low }}, \delta_{\mathrm{iw}, \mathrm{med}}$ and $\delta_{\mathrm{iw}}$, high treatments, respectively. The difference between the composition of the irrigation water and the initial $\delta_{\mathrm{sw}}$, ce was $0.29 \pm 0.35 \%$ VSMOW-SLAP for the $\delta_{\text {iw, low }}$ treatment, $0.58 \pm 0.22 \%$ VSMOW-SLAP for the $\delta_{\mathrm{iw}}$, med treatment and $1.04 \pm 0.05 \%$ VSMOW-SLAP for the $\delta_{\mathrm{iw}}$, high treatment. Evaporation during pre-incubation and gas measurements (Fig. 3) resulted in final $\delta_{\text {sw, ce (averaged }}$ between 0 and $5 \mathrm{~cm}$ depth and weighted by water content) of $-6.75 \pm 0.11,-4.17 \pm 0.36$ and $-0.55 \pm 0.07 \%$ o VSMOWSLAP for the $\delta_{\mathrm{iw}, \text { low }}, \delta_{\mathrm{iw}, \text { med }}$ and $\delta_{\mathrm{iw}}$, high treatments, respectively.

The $\delta_{\text {sw, ce }}$ of the methodological tests using soil where residual water was removed prior to labelling by oven drying was $-5.41 \pm 0.19 \%$ o VSMOW-SLAP, i.e. $0.57 \%$ more depleted than the labelling water. Similarly, the $\delta_{\mathrm{sw}-\mathrm{ce}}$ of the soil where residual water was removed by cryogenic extraction $(n=5)$ was $-5.01 \pm 0.18 \%$ VSMOW-SLAP and overlapped with the labelling water with a mean depletion of only $0.17 \%$. 
Table 2. Gas exchange data by irrigation water $\left(\delta_{\mathrm{iw}}\right)$ treatment at the three different incubation system inlet conditions $\left(\delta_{\mathrm{b}}\right)$. Means and standard deviations (in parenthesis) for total $\mathrm{CO}_{2}$ concentration in the bypass $\left(C_{\mathrm{b}}\right)$ and the chamber $\left(C_{\mathrm{a}}\right)$, the $\delta^{18} \mathrm{O}$ of $\mathrm{CO}_{2}$ in the bypass $\left(\delta_{\mathrm{b}}\right)$ and the chamber $\left(\delta_{\mathrm{a}}\right)$, and the net flux of $\mathrm{CO}_{2}\left(F_{\mathrm{R}}\right)$ and its $\delta^{18} \mathrm{O}\left(\delta_{\mathrm{R}}\right)$.

\begin{tabular}{|c|c|c|c|c|c|c|c|c|c|}
\hline & \multicolumn{3}{|c|}{$\delta_{\text {iw, low }}$} & \multicolumn{3}{|c|}{$\delta_{\mathrm{iw}, \mathrm{med}}$} & \multicolumn{3}{|c|}{$\delta_{\mathrm{iw}, \text { high }}$} \\
\hline & $\delta_{\mathrm{b}, \text { low }}$ & $\delta_{\mathrm{b}, \text { med }}$ & $\delta_{\mathrm{b}, \mathrm{high}}$ & $\delta_{\mathrm{b}, \text { low }}$ & $\delta_{\mathrm{b}, \mathrm{med}}$ & $\delta_{\mathrm{b}, \text { high }}$ & $\delta_{\mathrm{b}, \text { low }}$ & $\delta_{\mathrm{b}, \mathrm{med}}$ & $\delta_{\mathrm{b}, \text { high }}$ \\
\hline $\begin{array}{l}C_{\mathrm{b}} \\
(\mathrm{ppm})\end{array}$ & $\begin{array}{r}425.99 \\
(1.35)\end{array}$ & $\begin{array}{r}423.80 \\
(0.92)\end{array}$ & $\begin{array}{r}425.06 \\
(0.04)\end{array}$ & $\begin{array}{r}424.24 \\
(1.74)\end{array}$ & $\begin{array}{r}422.82 \\
(0.99)\end{array}$ & $\begin{array}{r}425.04 \\
(0.14)\end{array}$ & $\begin{array}{r}425.73 \\
(1.50)\end{array}$ & $\begin{array}{r}422.23 \\
(0.83)\end{array}$ & $\begin{array}{r}425.08 \\
(0.03)\end{array}$ \\
\hline $\begin{array}{l}C_{\mathrm{a}} \\
(\mathrm{ppm})\end{array}$ & $\begin{array}{r}482.13 \\
(9.79)\end{array}$ & $\begin{array}{r}480.28 \\
(8.56)\end{array}$ & $\begin{array}{r}481.24 \\
(6.39)\end{array}$ & $\begin{array}{l}495.26 \\
(11.09)\end{array}$ & $\begin{array}{l}494.20 \\
(12.71)\end{array}$ & $\begin{array}{l}496.78 \\
(14.59)\end{array}$ & $\begin{array}{r}488.80 \\
(3.93)\end{array}$ & $\begin{array}{r}485.06 \\
(3.52)\end{array}$ & $\begin{array}{r}488.01 \\
(2.87)\end{array}$ \\
\hline $\begin{array}{l}F_{\mathrm{R}} \\
\left(\mu \mathrm{mol} \mathrm{m}{ }^{-2} \mathrm{~s}^{-1}\right)\end{array}$ & $\begin{array}{r}1.98 \\
(0.31)\end{array}$ & $\begin{array}{r}1.99 \\
(0.30)\end{array}$ & $\begin{array}{r}1.98 \\
(0.23)\end{array}$ & $\begin{array}{r}2.50 \\
(0.43)\end{array}$ & $\begin{array}{r}2.51 \\
(0.42)\end{array}$ & $\begin{array}{r}2.53 \\
(0.52)\end{array}$ & $\begin{array}{r}2.22 \\
(0.17)\end{array}$ & $\begin{array}{r}2.21 \\
(0.12)\end{array}$ & $\begin{array}{r}2.22 \\
(0.10)\end{array}$ \\
\hline $\begin{array}{l}\delta_{\mathrm{b}} \\
\left(\% \circ \mathrm{VPDB}_{\mathrm{g}}\right)\end{array}$ & $\begin{array}{r}-26.80 \\
(0.25)\end{array}$ & $\begin{array}{r}-13.92 \\
(0.09)\end{array}$ & $\begin{array}{l}-3.63 \\
(0.15)\end{array}$ & $\begin{array}{r}-26.87 \\
(0.22)\end{array}$ & $\begin{array}{r}-13.97 \\
(0.17)\end{array}$ & $\begin{array}{l}-3.62 \\
(0.30)\end{array}$ & $\begin{array}{r}-26.86 \\
(0.06)\end{array}$ & $\begin{array}{r}-13.99 \\
(0.08)\end{array}$ & $\begin{array}{l}-3.58 \\
(0.11)\end{array}$ \\
\hline $\begin{array}{l}\delta_{\mathrm{a}} \\
\left(\% \circ \mathrm{VPDB}_{\mathrm{g}}\right)\end{array}$ & $\begin{array}{r}-22.48 \\
(0.26)\end{array}$ & $\begin{array}{r}-13.01 \\
(0.10)\end{array}$ & $\begin{array}{l}-5.56 \\
(0.19)\end{array}$ & $\begin{array}{r}-21.90 \\
(0.34)\end{array}$ & $\begin{array}{r}-12.36 \\
(0.09)\end{array}$ & $\begin{array}{l}-5.11 \\
(0.51)\end{array}$ & $\begin{array}{r}-21.12 \\
(0.23)\end{array}$ & $\begin{array}{r}-11.62 \\
(0.10)\end{array}$ & $\begin{array}{l}-4.20 \\
(0.17)\end{array}$ \\
\hline $\begin{array}{l}\delta_{\mathrm{R}} \\
\left(\% \circ \mathrm{VPDB}_{\mathrm{g}}\right)\end{array}$ & $\begin{array}{l}10.80 \\
(3.70)\end{array}$ & $\begin{array}{l}-6.05 \\
(1.22)\end{array}$ & $\begin{array}{r}-20.27 \\
(0.95)\end{array}$ & $\begin{array}{r}8.34 \\
(3.83)\end{array}$ & $\begin{array}{l}-2.67 \\
(1.12)\end{array}$ & $\begin{array}{r}-14.01 \\
(1.33)\end{array}$ & $\begin{array}{l}17.73 \\
(2.03)\end{array}$ & $\begin{array}{r}4.40 \\
(1.18)\end{array}$ & $\begin{array}{l}-8.36 \\
(0.74)\end{array}$ \\
\hline
\end{tabular}

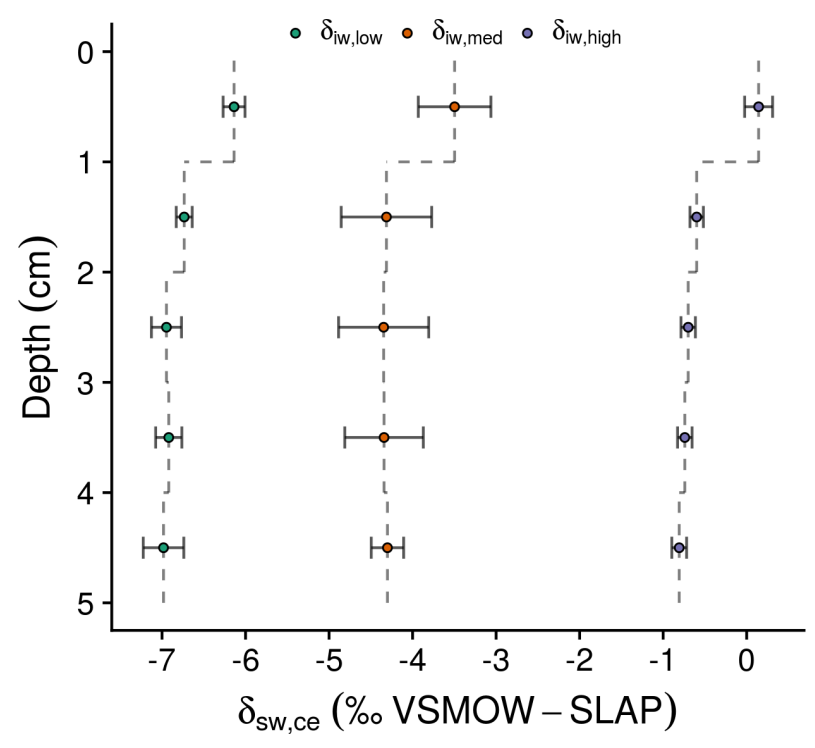

Figure 3. Incubation depth profiles of the $\delta^{18} \mathrm{O}$ of cryogenically extracted soil water $\left(\delta_{\mathrm{sw}}, \mathrm{ce}\right)$, at intervals of $0-1,1-2,2-3$ and $4-$ $5 \mathrm{~cm}$ below the surface. Symbols and error bars indicate means and standard deviations by irrigation water $\left(\delta_{\mathrm{iw}}\right)$ treatment and depth interval.

\subsection{Gas measurements}

The mean $\mathrm{CO}_{2}$ concentration, $C_{\mathrm{b}}$, of the three different inlet gases $\left(\delta_{\mathrm{b}, \text { low }}, \delta_{\mathrm{b} \text {, med }}\right.$ and $\left.\delta_{\mathrm{b} \text {, high }}\right)$ measured in the bypass line were between 422 and $426 \mathrm{ppm}$ for all water treatments, with standard deviations for individual gas mixtures and water treatments smaller than $2 \mathrm{ppm}$ (Table 2). The mean $\mathrm{CO}_{2}$ concentration, $C_{\mathrm{a}}$, measured in the chamber line for these inlet conditions varied between 480 and 497 ppm, with standard deviations for individual gas mixtures and water treatments between 2 and $15 \mathrm{ppm}$ (Table 2). Subsequently, the resultant mean of $\mathrm{CO}_{2}$ fluxes, $F_{\mathrm{R}}$ (Eq. 5), for $\delta_{\mathrm{b}, \text { low }}, \delta_{\mathrm{b} \text {, med }}$ and $\delta_{\mathrm{b}, \text { high }}$ were $1.98 \pm 0.01 \mu \mathrm{mol} \mathrm{m}^{-2} \mathrm{~s}^{-1}$ for the $\delta_{\mathrm{iw}}$, low treatment, $2.51 \pm 0.01 \mu \mathrm{mol} \mathrm{m}^{-2} \mathrm{~s}^{-1}$ for the $\delta_{\mathrm{iw} \text {, med }}$ treatment and $2.22 \pm 0.01 \mu \mathrm{mol} \mathrm{m}^{-2} \mathrm{~s}^{-1}$ for the $\delta_{\text {iw, high treat- }}$ ment, with standard deviations for individual gas mixtures and water treatments between 0.1 and $0.6 \mu \mathrm{mol} \mathrm{m}^{-2} \mathrm{~s}^{-1}$. The similarity within water treatment demonstrates the good repeatability of the experiment, however, the greater variability in $C_{\mathrm{a}}$ compared to $C_{\mathrm{b}}$ indicates that steady-state conditions may not have always been fully attained (the order of inlet conditions was varied among incubations). Indeed, whilst there was no general relationship between $F_{\mathrm{R}}$ and $C_{\mathrm{b}}, F_{\mathrm{R}}$ linearly decreased with time $\left(r^{2}=0.83\right.$ to 0.99$)$, at a rate of between 0.078 and $0.31 \mu \mathrm{mol} \mathrm{m}^{-2} \mathrm{~h}^{-1}$ over the course of all the incubations. Because of these trends, incubation mean ratios of $C_{\mathrm{a}} / F_{\mathrm{R}}$ were $10200 \pm 1200,8350 \pm 1100$ and $9140 \pm 320 \mathrm{~s} \mathrm{~m}^{-1}$ for the $\delta_{\mathrm{iw}, \text { low }}, \delta_{\mathrm{iw} \text {, med }}$ and $\delta_{\mathrm{iw} \text {, high }}$ treatments, respectively. Standard deviations associated with the ratio for individual incubations were between 240 and $425 \mathrm{~s} \mathrm{~m}^{-1}$.

Mean $\delta^{18} \mathrm{O}$ of $\mathrm{CO}_{2}$ in the bypass, $\delta_{\mathrm{b}}$, and chamber, $\delta_{\mathrm{a}}$, lines for the different water treatments and inlet conditions are given in Table 2 together with the resultant exchange, $\delta_{\mathrm{R}}$ (Eq. 6). Unlike $F_{\mathrm{R}}$ there was no general relationship between $\delta_{\mathrm{R}}$ and time but, as expected, $\delta_{\mathrm{R}}$ was strongly negatively correlated with $\delta_{\mathrm{b}}\left(r^{2}>0.95\right.$ in all the incubations). Generally variability in these measurements was largest for the $\delta_{\mathrm{b} \text {, low }}$ gas mixture. 
Table 3. Model solutions by irrigation water $\left(\delta_{\text {iw }}\right)$ treatment. Means $(n=6)$ and standard deviations (in parenthesis) for the piston velocity of $\mathrm{CO}_{2}$ assuming a semi-infinite soil depth $\left(v_{\text {inv }}\right)$, the piston velocity of $\mathrm{CO}_{2}$ assuming a finite soil depth $\left(\widetilde{v}_{\text {inv }}\right)$, the apparent rate of exchange between $\mathrm{CO}_{2}$ and soil water $\left(k_{\text {iso }}\right)$, the effective diffusional fraction of $\mathrm{CO}_{2}$ assuming a finite soil depth $(\widetilde{a})$, and the $\delta^{18} \mathrm{O}$ of soil water in equilibrium with $\mathrm{CO}_{2}$ as determined from gas flux measurements $\left(\delta_{\mathrm{sw}}\right.$, eq $)$. Superscript letters following each mean and deviation indicate significant differences (one-way analysis of variance and Tukey's HSD, $p<0.01$ ) among $\delta_{\text {iw }}$ treatments.

\begin{tabular}{lrrrrr}
\hline Treatment & $\begin{array}{r}v_{\text {inv }} \\
\left(\mathrm{mm} \mathrm{s}^{-1}\right)\end{array}$ & $\begin{array}{r}\widetilde{v}_{\text {inv }} \\
\left(\mathrm{mm} \mathrm{s}^{-1}\right)\end{array}$ & $\begin{array}{r}k_{\text {iso }} \\
\left(\mathrm{s}^{-1}\right)\end{array}$ & $\begin{array}{r}\tilde{a} \\
(\% \circ \text { VPDB }\end{array}$ & $\begin{array}{r}\delta_{\text {sw, eq }} \\
(\% \circ \text { VSMOW-SLAP })\end{array}$ \\
\hline$\delta_{\text {iw, low }}$ & $0.179(0.011)^{\mathrm{a}}$ & $0.181(0.011)^{\mathrm{a}}$ & $0.080(0.009)^{\mathrm{a}}$ & $5.36(0.16)^{\mathrm{a}}$ & $-9.31(0.20)^{\mathrm{c}}$ \\
$\delta_{\text {iw, med }}$ & $0.158(0.021)^{\mathrm{a}}$ & $0.162(0.02)^{\mathrm{a}}$ & $0.063(0.015)^{\mathrm{a}}$ & $4.88(0.43)^{\mathrm{a}}$ & $-7.04(0.52)^{\mathrm{b}}$ \\
$\delta_{\text {iw, high }}$ & $0.168(0.014)^{\mathrm{a}}$ & $0.171(0.013)^{\mathrm{a}}$ & $0.071(0.012)^{\mathrm{a}}$ & $5.14(0.29)^{\mathrm{a}}$ & $-4.16(0.18)^{\mathrm{a}}$ \\
\hline
\end{tabular}

\subsection{Estimates of $\boldsymbol{k}_{\text {iso }}$ and $\delta_{\text {sw, eq }}$}

In all the incubations, $\delta_{\mathrm{a}}$ and $\delta_{\mathrm{R}}$ were strongly $\left(r^{2}>0.93\right)$ and negatively correlated (Fig. 4). The slope, $m$, of the linear regressions were broadly similar among water treatments, with means of $-1.83 \pm 0.25$ for the $\delta_{\text {iw, low }}$ treatment, $-1.32 \pm 0.25$ for the $\delta_{\text {iw, med }}$ treatment and $-1.53 \pm 0.15$ for the $\delta_{\text {iw, high }}$ treatment. In contrast, the intercept, $c$, of the linear regressions between $\delta_{\mathrm{a}}$ and $\delta_{\mathrm{R}}$ were more distinct, with treatment means of $-30.17 \pm 2.14 \%$ o $\mathrm{VPDB}_{\mathrm{g}}$ for the $\delta_{\mathrm{iw}}$, low treatment, $-20.08 \pm 2.66 \%$ o $\mathrm{VPDB}_{\mathrm{g}}$ for the $\delta_{\mathrm{iw}}$, med treatment and $-14.29 \pm 1.21 \% \mathrm{VPDB}_{\mathrm{g}}$ for the $\delta_{\mathrm{iw}}$, high treatment.

The mean piston velocity assuming a semi-infinite soil column, $v_{\text {inv }}$ (Eq. 3a), varied between 0.16 and $0.18 \mathrm{~mm} \mathrm{~s}^{-1}$ (Table 3). Accounting for the finite depth of the soil column lead to $\widetilde{v}_{\text {inv }}$ values (Eq. 7) that were systematically but only marginally larger (Table 3 ), mostly because soil depth, $z_{\max }$, had been chosen to minimise this difference (Table 1 and Fig. S2). These values led to $\mathrm{CO}_{2}-\mathrm{H}_{2} \mathrm{O}$ isotopic exchange rates, $k_{\text {iso }}$, that were not significantly different between treatments (Table 3).

Estimates of the effective fractionation, $\widetilde{a}$ (Eq. 10), were approximately half the full fractionation of $8.8 \%$ (Table 3 ). Expectedly, estimated values of the isotopic composition of $\mathrm{CO}_{2}$ in equilibrium with soil water, $\delta_{\text {eq }}$ (Eq. $3 \mathrm{~b}$ ), were significantly different among water treatments. These values led to equivalent values of the isotopic composition of soil water in equilibrium with $\mathrm{CO}_{2}, \delta_{\text {sw, eq }}$ (Eq. 11), that were also significantly different between treatments (Table 3 ) and surprisingly more depleted than the isotopic composition of cryogenically extracted soil water, $\delta_{\mathrm{sw}}$, ce, at all depths (Fig. 3 ).

\section{Discussion}

Our first aim was to confirm the assumption that the isotopic compositions of the $\mathrm{CO}_{2}$ flux, $\delta_{\mathrm{R}}$, and the $\mathrm{CO}_{2}$ of the air at the soil-air interface, $\delta_{\mathrm{a}}$, are linearly related (Eq. 1). This appears to be a good approximation for our data, with strong correlations between $\delta_{\mathrm{R}}$ and $\delta_{\mathrm{a}}$ in all experiments (Fig. 4). However, a number of other assumptions inherent to apply-

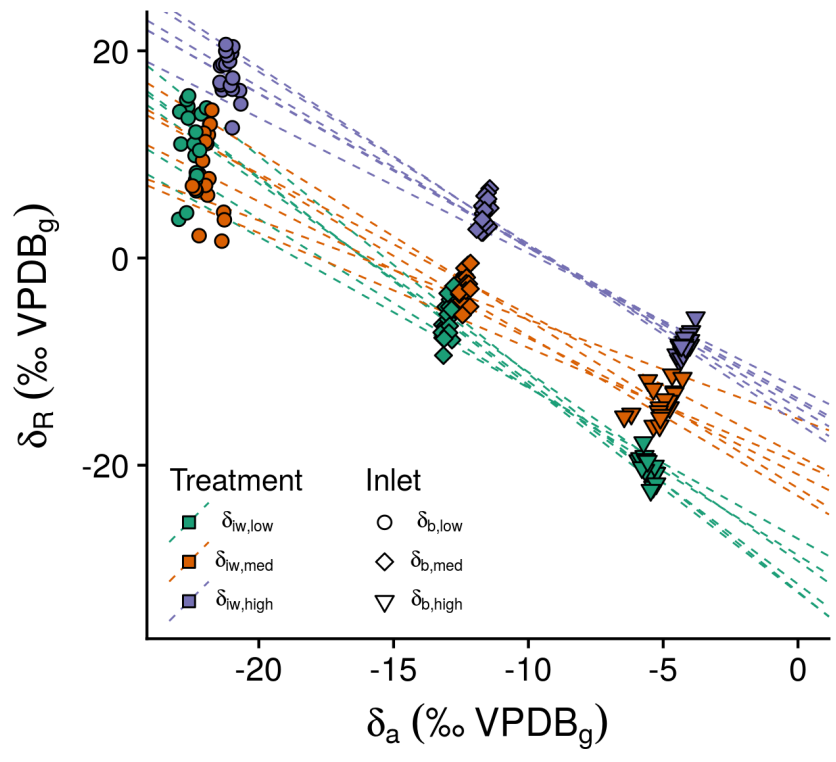

Figure 4. Relationships between the $\delta^{18} \mathrm{O}$ of soil-atmosphere $\mathrm{CO}_{2}$ exchange $\left(\delta_{\mathrm{R}}\right)$ and the $\delta^{18} \mathrm{O}$ of $\mathrm{CO}_{2}$ in the chamber line $\left(\delta_{\mathrm{a}}\right)$ by irrigation water $\left(\delta_{\mathrm{iw}}\right)$ treatment. Symbol shapes indicate measurements made at different inlet conditions $\left(\delta_{\mathrm{b}}\right)$ that varied in terms of their $\delta^{18} \mathrm{O}$ of $\mathrm{CO}_{2}$. Dashed lines indicate linear regressions for individual incubations.

ing the model described by Eq. (1) in this way may influence our results. Namely, that $\mathrm{CO}_{2}$ production profiles were constant with depth and that gas flux measurements were made under steady-state conditions (Tans, 1998). The first point is unlikely to be an issue here because care was taken to homogenise the soils before each gas exchange measurement (see Sect. 2.1) and the total period between preparation and measurement $(24 \mathrm{~h})$ was too short to allow large gradients, for example in soil moisture, that might cause an unequal respiration profile to develop. Potential deviations from steadystate conditions require more attention. A period of $21 \mathrm{~min}$ was included before the measurements from which fluxes were calculated, not only at the initial connection of an incubation chamber but also after each subsequent switch of the inlet conditions (Fig. 2). This period was chosen based on 
initial tests indicating that 10 min was sufficient for the concentration and composition of $\mathrm{CO}_{2}$ to stabilise in an empty chamber and calculations indicating that full isotopic equilibrium of the $\mathrm{CO}_{2}-\mathrm{H}_{2} \mathrm{O}$ system, given the acidity and temperature of the soil, should theoretically be reached within $12 \mathrm{~min}$ even at uncatalysed rates (Uchikawa and Zeebe, 2012). However, our results showed that the net soil $\mathrm{CO}_{2}$ flux, $F_{\mathrm{R}}$, systematically decreased with time by about $10 \%$ on average between the first and last measurements within an incubation. This indicates that our measurements did not strictly adhere to the assumption of steady state. This trend probably reflects a combination of dissolved $\mathrm{CO}_{2}$ de-gassing from the soil water as a result of small differences between preincubation and incubation $\mathrm{CO}_{2}$ concentrations and, probably more importantly, the temporal response of soil respiration to re-wetting (Birch, 1958; Jarvis et al., 2007). As such, the ratio between the concentration of $\mathrm{CO}_{2}$ at the soil surface, $C_{\mathrm{a}}$, and $F_{\mathrm{R}}$ is not strictly constant and this introduces uncertainties into the estimations of the apparent rate of exchange, $k_{\text {iso }}$, and the isotopic composition of soil water, $\delta_{\mathrm{sw}-\mathrm{eq}}$, that are considerably larger than those associated with individual gas measurements. Indeed, propagating this within-incubation variability in the ratio of $C_{\mathrm{a}} / F_{\mathrm{R}}$ leads to within-incubation uncertainties in $k_{\text {iso }}$ of around $0.01 \mathrm{~s}^{-1}$ for all treatments and within-incubation uncertainties in $\delta_{\mathrm{sw}-\mathrm{eq}}$ of $0.45,0.37$ and $0.24 \%$ or the $\delta_{\text {iw, low }}, \delta_{\text {iw, med }}$ and $\delta_{i w, ~ h i g h}$ treatments. These within-incubation uncertainties are of the same order of magnitude as the variability in treatment means (Table 3), indicating that this temporal deviation from steadystate conditions may be the cause of much of the reported variability. This variability could be reduced in future studies by working with fresh soils or allowing longer acclimatisation periods after re-wetting, provided efforts are made to limit the development of heterogeneity in the soil profile. As the linearity between $\delta_{\mathrm{R}}$ and $\delta_{\mathrm{a}}$ appears strong, variability could also be reduced by considering two rather than three inlet conditions to shorten the overall measurement time.

Secondly, we aimed to compare estimates of $\delta_{\text {sw, eq }}$ determined from the gas flux measurements with $\delta_{\mathrm{sw}}$, ce measured for the extracted bulk soil water. Given the relatively constant profile of $\delta_{\mathrm{sw}}$, ce with depth (Fig. 3) and the fact that total soil depth, $z_{\max }$, was shallower than that required for full convergence between the semi-infinite and finite soil depth model solutions (Table 3, Fig. S2), the estimates of $\delta_{\text {sw, eq }}$ reported likely reflect interaction between $\mathrm{CO}_{2}$ and soil water across the total soil depth (Kapiluto et al., 2007). Whilst $\delta_{\mathrm{sw} \text {, eq }}$ estimates were distinct among water treatments, they were also consistently more depleted than $\delta_{\text {sw, ce, with mean }}$

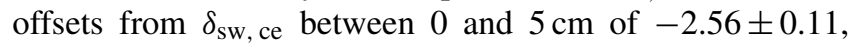
$-2.87 \pm 0.56$ and $-3.61 \pm 0.23 \%$ VSMOW-SLAP for the $\delta_{\text {iw, low }}, \delta_{\text {iw, med }}$ and $\delta_{\text {iw, high }}$ treatments, respectively. Given the difference between the externally assigned value of $-3.45 \pm 0.02 \% \mathrm{VPDB}_{\mathrm{g}}$ for the gas cylinder used as the $\delta_{\mathrm{b} \text {, high }}$ inlet condition and its measurement, with treatment means of $-3.63 \pm 0.15,-3.62 \pm 0.3$ and $-3.58 \pm 0.11 \%$ o
$\mathrm{VPDB}_{\mathrm{g}}$ for $\delta_{\mathrm{iw}}$, low,$\delta_{\mathrm{iw}}$, med and $\delta_{\mathrm{iw}}$, high, respectively, we find no evidence that an offset between the calibration of our gas and water measurement scales could account for the size of the offset observed. Similarly, we find no evidence for large biases in our cryogenic extraction methodology as $\delta_{\text {sw, ce }}$ and composition of the labelling water overlapped in the tests where residual water was removed under extraction conditions prior to label addition (Orlowski et al., 2013, 2016b). This suggests that the offset between $\delta_{\text {sw, eq }}$ and $\delta_{\text {sw, ce }}$ is the result of $\mathrm{CO}_{2}$ interacting with a water pool whose isotopic composition is more depleted than $\delta_{\mathrm{sw}}$, ce. Differences in the water pools characterised by different methodologies for determining the isotopic composition of soil waters are well known, with the cryogenic extraction method being expected to remove macro-pore, micro-pore, hygroscopic and potentially crystalline water, whilst the static equilibration of soils with $\mathrm{CO}_{2}$ is expected to principally reflect only the macropore and micro-pore pools (Hsieh et al., 1998b; Orlowski et al., 2016b; Sprenger et al., 2015). For this reason, we might expect $\delta_{\text {sw, eq }}$ derived here to reflect the isotopic composition of macro-pore and micro-pore pools and $\delta_{\mathrm{sw}}$, ce to reflect both these as well as hygroscopic and crystalline waters. However, disregarding the crystalline water pool in this predominately sandy soil, this would suggest that the isotopic composition of the hygroscopic pool would have to be considerably more positive than that of the macro-pore and micro-pore water pools in order to account for the fact that $\delta_{\mathrm{sw}}$, eq estimates were more negative than $\delta_{\mathrm{sw} \text {, ce }}$. Contrary to this, extraction of water from the air-dried soil, of which hygroscopic water presumably represents a greater portion of the total water pool than in re-wetted samples, yielded a $\delta_{\text {sw, ce }}$ more depleted than that of the freshly sampled soil and the initial compositions of both the $\delta_{\mathrm{iw}}$, med and $\delta_{\mathrm{iw}}$, high treatments. This suggests that this residual pool in fact reflects the potentially rapid and dynamic exchange with atmospheric vapour during storage (Lin and Horita, 2016; Orlowski et al., 2016b; Savin and Epstein, 1970). Indeed, the fact that about $10 \%$ of water in the re-wetted soils consisted of this residual pool helps account for the differences between the composition of the added water and initial $\delta_{\mathrm{sw}-\mathrm{ce}}$ across the water treatments. Observations that fractionation occurs between water associated with cations and anions present in solution or at mineral surfaces (Oerter et al., 2014), organic particle surfaces (Chen et al., 2016), and pore surfaces (Lin and Horita, 2016) and bulk water pools may help explain our data. In particular, Chen et al. (2016) found that the composition of the water bound to organic particle surfaces could be up to $4 \%$ more depleted than bulk water, with a greater fractionation at higher volumetric ratios of solids to water. Such a depletion in bound (hygroscopic) water would explain our data, given the relatively low water content of the soil studied. However, this requires us to consider that $\mathrm{CO}_{2}$ is being heavily influenced by exchange with hygroscopic water under our experimental conditions. Such interaction between $\mathrm{CO}_{2}$ and hygroscopic water may be plausible as surface wa- 


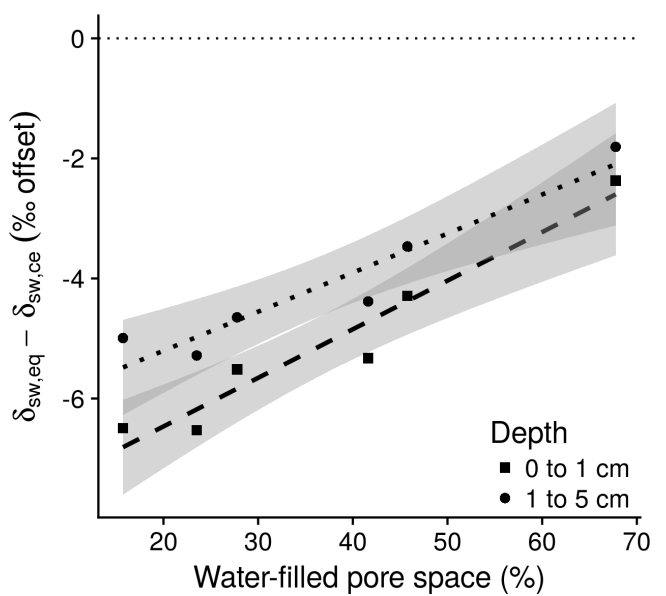

Figure 5. Relationships between water-filled pore space and the difference between estimates of the $\delta^{18} \mathrm{O}$ of soil water in equilibrium with $\mathrm{CO}_{2}$, as estimated from gas flux measurements $\left(\delta_{\mathrm{sw}, \mathrm{eq}}\right)$, and that estimated by cryogenic extraction $\left(\delta_{\mathrm{sw}}\right.$, ce $)$ at depths of $0-1 \mathrm{~cm}$ (squares) and $1-5 \mathrm{~cm}$ (circles). Dashed lines and shaded areas indicate the linear regressions and associated $95 \%$ confidence intervals for the two sampling depths.

ter films are where microbial communities expressing CA are likely to be present and active. If interaction with hygroscopic water were the cause of this observation, we should expect to see a smaller offset between $\delta_{\text {sw, eq }}$ and $\delta_{\text {sw, ce }}$ at higher water content because, as water content increases, so does the proportion of non-hygroscopic to hygroscopic water that $\mathrm{CO}_{2}$ interacts with during the slow process of liquid phase diffusion (4 orders of magnitude lower than gas phase diffusion). We estimated that, even at the uncatalysed rate of hydration, $\mathrm{CO}_{2}$ molecules would be fully equilibrated if they had to diffuse through about $0.5 \mathrm{~mm}$ of water. Whilst this is not realistic for water films adsorbed onto pore surfaces, such path lengths are plausible for filled capillaries as the soil-pore network approaches saturation (Lebeau and Konrad, 2010; Tokunaga, 2011; Tuller and Or, 2001). We tested this by creating and measuring an additional six incubations, following the methods described above, that were re-wetted with different amounts of the same water to achieve water contents ranging from about 15 to $70 \%$ water-filled pore space. The differences between estimated $\delta_{\mathrm{sw}}$ eq and $\delta_{\mathrm{sw}}$, ce determined for sampling depths of $0-1 \mathrm{~cm}\left(r^{2}=0.92\right)$ and $1-5 \mathrm{~cm}\left(r^{2}=0.88\right)$ were positively and linearly correlated with water-filled pore space across these incubations (Fig. 5). The fact that these relationships indicate the offset decreases at higher water contents may indeed support the inference that estimates of $\delta_{\mathrm{sw}, \text { eq }}$ are being influenced by fractionation between surface and bulk water pools in our measurements.

Finally, we aimed to compare the sensitivity of estimates of $k_{\text {iso }}$ to $\delta_{\text {sw }}$. Estimates of $k_{\text {iso }}$ ranged from 6.8 to 14.6 times greater than the theoretical uncatalysed rate of $\mathrm{CO}_{2}$ $\mathrm{H}_{2} \mathrm{O}$ isotopic exchange of $0.006 \mathrm{~s}^{-1}$ for the incubation con- ditions (Uchikawa and Zeebe, 2012). This enhancement of the apparent over the uncatalysed rate of hydration indicates that the reaction is indeed being catalysed by the presence of $\mathrm{CA}$ in these soils. After considering differences in the value of uncatalysed rate of $\mathrm{CO}_{2}-\mathrm{H}_{2} \mathrm{O}$ exchange used, these rates are on the lower end of those reported from soil chambers deployed in the forest where soil used here was collected (Wingate et al., 2009, 2010). Our estimates of $k_{\text {iso }}$ were not distinct among water treatments (Table 3), supporting the idea that our new approach is robust enough to assay soil CA activity in the absence of information about $\delta_{\mathrm{sw}}$. This is beneficial as this approach also does not rely on any assumption about which soil water pool the $\mathrm{CO}_{2}$ must equilibrate with, as such an assumption could introduce strong biases in the

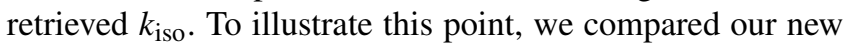
approach with previous studies (Wingate et al., 2009, 2008) where $\delta_{\text {sw }}$ has been used to determine $k_{\text {iso }}$ from Eqs. (1) and (2). For this, we replaced $v_{\text {inv }}$ and $a$ in these equations with $\widetilde{v}_{\text {inv }}$ (Eq. 7) and $\widetilde{a}$ (Eq. 10) and iteratively solved for $\widetilde{v}_{\text {inv }}$ using $\delta_{\text {sw, ce }}$ and gas measurements made at the individual inlet conditions reported here. In doing so we highlight the potential sensitivity of estimating $k_{\text {iso }}$ in this way to the combination of both $\delta_{\mathrm{sw}}$ and the inlet conditions. Equivalent values of $\delta_{\text {eq }}$ calculated (Eq. 11) from $\delta_{\text {sw, ce }}$ between 0 and $5 \mathrm{~cm}$ were $-6.15 \pm 0.11,-3.57 \pm 0.36$ and $0.05 \pm 0.07 \%$ o $\mathrm{VPDB}_{\mathrm{g}}$ for the $\delta_{\mathrm{iw}, \text { low }}, \delta_{\mathrm{iw} \text {, med }}$ and $\delta_{\mathrm{iw} \text {, high }}$ treatments, respectively. Means for $k_{\text {iso }}$ estimated in this way using measurements made at $\delta_{\mathrm{b} \text {, low }}$ were $0.042 \pm 0.005,0.029 \pm 0.008$ and $0.035 \pm 0.003 \mathrm{~s}^{-1}$ for the $\delta_{\mathrm{iw}}$, low,$\delta_{\mathrm{iw}}$, med and $\delta_{\mathrm{iw}}$, high treatments, respectively. These rates are roughly half the size of $k_{\text {iso }}$ estimated from regression among multiple inlet conditions (Table 3). Positive solutions for $k_{\text {iso }}$ estimated using measurements made at $\delta_{\mathrm{b}}$, med were not found for all incubations and estimates were smaller still, with means of $0.006 \pm 0.002,0.008 \pm 0.005$ and $0.015 \pm 0.004 \mathrm{~s}^{-1}$ for the $\delta_{\text {iw, low }}(n=3), \delta_{\text {iw, med }}(n=5)$ and $\delta_{\text {iw, high }}(n=6)$ treatments, respectively. No solution was found for $k_{\text {iso }}$ estimated using measurements made at $\delta_{\mathrm{b}, \text { high }}$ for the $\delta_{\mathrm{iw} \text {, med }}$ and $\delta_{i w}$, high water treatments, whilst the estimates for $\delta_{\mathrm{iw}}$, low water treatment were 2 orders of magnitude larger with a mean of $3.18 \pm 2.6 \mathrm{~s}^{-1}$, i.e. more than 500 times larger than the uncatalysed rate. Situations where no solution is found arise in cases where $\left(\delta_{\mathrm{eq}}-\delta_{\mathrm{R}}\right)\left(\delta_{\mathrm{eq}}-\delta_{\mathrm{a}}\right) \geq 0$. These cases and the considerable variability in $k_{\text {iso }}$ among water treatments under different inlet conditions reflect the presence of an asymptote in the model response when $\delta_{\text {eq }}$ and $\delta_{\mathrm{a}}$ are similar (Eq. 1). In this region of the response, relatively small changes in $\delta_{\text {eq }}$ result in large changes in $k_{\text {iso }}$, as seen among estimates for the $\delta_{\text {iw, low }}$ water treatment made using $\delta_{\mathrm{b}, \text { low }}$,

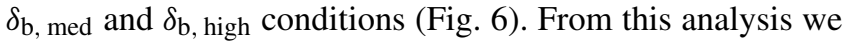
can see that this can be problematic when attempts to estimate $k_{\text {iso }}$ are made under field conditions. The oxygen isotopic composition of atmospheric $\mathrm{CO}_{2}$ typically ranges from -1.5 to $+1.5 \%$ o VPDB $_{\mathrm{g}}$ (Welp et al., 2011). The isotopic composition of superficial soil water varies as a function of 


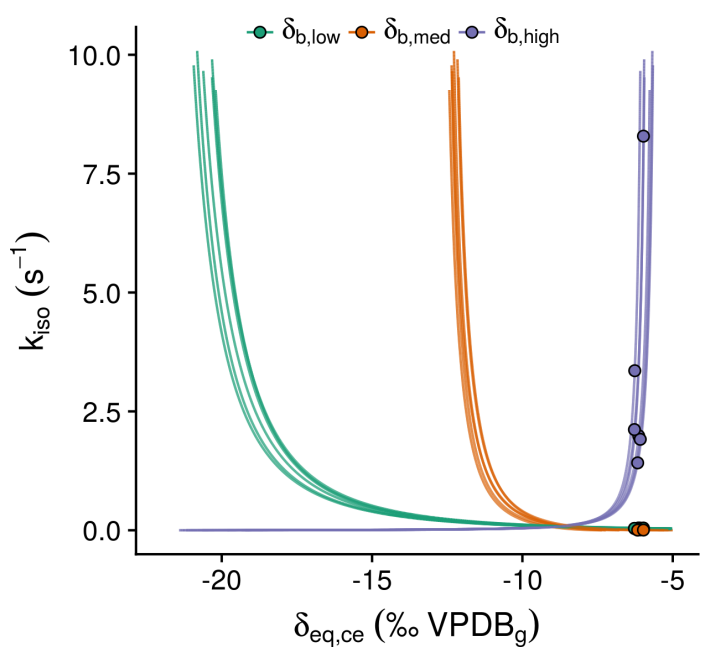

Figure 6. Model relationships between the apparent rate of exchange $\left(k_{\text {iso }}\right)$ and the $\delta^{18} \mathrm{O}$ of $\mathrm{CO}_{2}$ in equilibrium with soil water $\left(\delta_{\text {eq, ce }}\right)$. These $\delta_{\text {eq, ce }}$ values were assumed from the depthaveraged $\delta^{18} \mathrm{O}$ of cryogenically extracted water for the incubations that received the $\delta_{\text {iw, low }}\left(\delta^{18} \mathrm{O}\right.$ of $-6.74 \pm 0.03 \%$ VSMOWSLAP) irrigation water. Colours indicate the different responses for the same set of incubations at the three inlet conditions that differed by their $\delta^{18} \mathrm{O}$ of $\mathrm{CO}_{2}\left(\delta_{\mathrm{b}}\right)$.

latitudinal and altitudinal patterns in the composition of precipitation and the subsequent influence of evapotranspiration, but is frequently reported in the range of -10 to $+5 \%$ VSMOW (Barbeta et al., 2015; Brooks et al., 2010; Dawson et al., 2002; Hsieh et al., 1998a). This suggests that values of $\delta_{\text {eq }}$, after accounting for the influence of soil temperature and difference between scales in converting from $\delta_{\mathrm{sw}}$ (Eq. 11), can overlap the $\delta^{18} \mathrm{O}$ of atmospheric $\mathrm{CO}_{2}$ under normal conditions (Wingate et al., 2009).

\section{Conclusions}

We have demonstrated that a strong linear correlation existed between $\delta_{\mathrm{R}}$ and $\delta_{\mathrm{a}}$, suggesting that we should also be able to derive $k_{\text {iso }}$ and $\delta_{\text {sw, eq }}$ from only two inlet conditions. This is beneficial, as it is likely to reduce the uncertainty in these estimates introduced by temporal changes in the $\mathrm{CO}_{2}$ flux. We also reported an offset between $\delta_{\mathrm{sw}, \text { ce }}$ and $\delta_{\mathrm{sw}, \text { eq }}$, which indicates that bulk soil water may not always be the principal pool of interaction for $\mathrm{CO}_{2}$. Such an offset might be explained by an isotopic fractionation between bound and bulk water pools, with the sign of this offset seeming to indicate that $\mathrm{CO}_{2}$ interacts preferentially with bound water under our experiment conditions. Clearly, a better understanding of fine-scale heterogeneity in soil water isotope composition and microbial activity is required. Finally, our estimates of $k_{\text {iso }}$ were independent of the isotopic composition of the irrigation water used, suggesting our approach is a robust assay of the activity, even in soils with low CA activities such as those reported here. Given the sensitivity of $k_{\text {iso }}$ when estimated using a single $\mathrm{CO}_{2}$ composition and prescribed values of $\delta_{\text {eq }}$, our approach clearly represents a more conservative and robust method. To better understand the cycling of oxygen isotopes of $\mathrm{CO}_{2}$ within soils, further work is required to understand the physical processes controlling fractionation between soil water pools and the relation of $\mathrm{CO}_{2}$ transport, microbial communities and their activity to these pools.

Data availability. The underlying research data is part of European Research Council grant no. 338264 and will be made publicly accessible at the end of the grant. The data may be requested from the corresponding author by email.

\section{The Supplement related to this article is available online at https://doi.org/10.5194/hess-21-6363-2017- supplement.}

Author contributions. SJ, JO, JS, TL, AB and LW developed the modelling and data processing approach. SW, JS and SJ designed and built the gas exchange system. SJ and SW conducted gas flux measurements. NS, NF, JM and SJ tested the water extraction system and analysis system and conducted the soil water extractions and water analysis. SJ wrote the paper with contributions from all authors.

Competing interests. The authors declare that they have no conflict of interest.

Acknowledgements. We would like to thank Régis Burlett, Callum Tyler, Thomas Sajus and Jason West for their input in the laboratory and development of the experiment. This project has received funding from the European Research Council (ERC) under the European Union's Seventh Framework Programme (FP7/2007-2013) (grant agreement no. 338264) awarded to Lisa Wingate. The salary of Joana Sauze was funded by the Agence Nationale de la Recherche (ANR, project ORCA) and the INRA departments EA and EFPA.

Edited by: Erwin Zehe

Reviewed by: Matthias Sprenger and one anonymous referee

\section{References}

Badger, M.: The roles of carbonic anhydrases in photosynthetic CO2 concentrating mechanisms, Photosynth. Res., 77, 83, https://doi.org/10.1023/A:1025821717773, 2003.

Badger, M. R. and Price, G. D.: The Role of Carbonic Anhydrase in Photosynthesis, Annu. Rev. Plant Phys., 45, 369-392, https://doi.org/10.1146/annurev.pp.45.060194.002101, 1994. 
Banks, E. D., Taylor, N. M., Gulley, J., Lubbers, B. R., Giarrizzo, J. G., Bullen, H. A., Hoehler, T. M., and Barton, H. A.: Bacterial Calcium Carbonate Precipitation in Cave Environments: A Function of Calcium Homeostasis, Geomicrobiol. J., 27, 444454, https://doi.org/10.1080/01490450903485136, 2010.

Barbeta, A., Mejía-Chang, M., Ogaya, R., Voltas, J., Dawson, T. E., and Peñuelas, J.: The combined effects of a long-term experimental drought and an extreme drought on the use of plant-water sources in a Mediterranean forest, Glob. Change Biol., 21, 12131225, https://doi.org/10.1111/gcb.12785, 2015.

Bates, D., Mächler, M., Bolker, B., and Walker, S.: Fitting Linear Mixed-Effects Models Using 1me4, J. Stat. Softw., 67, 1-48, https://doi.org/10.18637/jss.v067.i01, 2015.

Berman, E. S. F., Levin, N. E., Landais, A., Li, S., and Owano, T.: Measurement of $\delta^{18} \mathrm{O}, \delta^{17} \mathrm{O}$, and ${ }^{17} \mathrm{O}$-excess in Water by Off-Axis Integrated Cavity Output Spectroscopy and Isotope Ratio Mass Spectrometry, Anal. Chem., 85, 10392-10398, https://doi.org/10.1021/ac402366t, 2013.

Birch, H. F.: The effect of soil drying on humus decomposition and nitrogen availability, Plant Soil, 10, 9-31, https://doi.org/10.1007/BF01343734, 1958.

Bowling, D. R., Sargent, S. D., Tanner, B. D., and Ehleringer, J. R.: Tunable diode laser absorption spectroscopy for stable isotope studies of ecosystem-atmosphere $\mathrm{CO} 2$ exchange, Agr. Forest Meteorol., 118, 1-19, https://doi.org/10.1016/S01681923(03)00074-1, 2003.

Brenninkmeijer, C. A. M., Kraft, P., and Mook, W. G.: Oxygen isotope fractionation between $\mathrm{CO}_{2}$ and $\mathrm{H}_{2} \mathrm{O}$, Chem. Geol., 41, 181190, https://doi.org/10.1016/S0009-2541(83)80015-1, 1983.

Brooks, J. R., Barnard, H. R., Coulombe, R., and McDonnell, J. J.: Ecohydrologic separation of water between trees and streams in a Mediterranean climate, Nat. Geosci., 3, 100-104, https://doi.org/10.1038/ngeo722, 2010.

Carrio, J. H.: Allanvar: Allan Variance Analysis, available at: https: //CRAN.R-project.org/package=allanvar, last access: 10 May 2015.

Chen, G., Auerswald, K., and Schnyder, H.: ${ }^{2} \mathrm{H}$ and ${ }^{18} \mathrm{O}$ depletion of water close to organic surfaces, Biogeosciences, 13, 31753186, https://doi.org/10.5194/bg-13-3175-2016, 2016.

Ciais, P., Sabine, C., Bala, G., Bopp, L., Brovkin, V., Canadell, J., Chhabra, A., DeFries, R., Galloway, J., Heimann, M., Jones, C., Le Quéré, C., Myneni, R., Piao, S. and Thornton, P.: Carbon and Other Biogeochemical Cycles, in: Climate Change 2013: The Physical Science Basis, Contribution of Working Group I to the Fifth Assessment Report of the Intergovernmental Panel on Climate Change, edited by: Stocker, T., Qin, D., Plattner, G.-K., Tignor, M., Allen, S., Boschung, J., Nauels, A., Xia, Y., Bex, V., and Midgley, P., Cambridge University Press, Cambridge, United Kingdom and New York, NY, USA, 465-570, 2013.

Crawley, M. J.: The R Book, Wiley, Chichester, West Sussex, United Kingdom, 2007.

Dawson, T. E., Mambelli, S., Plamboeck, A. H., Templer, P. H., and Tu, K. P.: Stable isotopes in plant ecology, Annu. Rev. Ecol. Syst., 33, 507-559, https://doi.org/10.1146/annurev.ecolsys.33.020602.095451, 2002.

de Mendiburu, F.: Agricolae: Statistical Procedures for Agricultural Research, available at: https://CRAN.R-project.org/package= agricolae, last access: 1 July 2016.
Farquhar, G. D., Lloyd, J., Taylor, J. A., Flanagan, L. B., Syvertsen, J. P., Hubick, K. T., Wong, S. C., and Ehleringer, J. R.: Vegetation effects on the isotope composition of oxygen in atmospheric $\mathrm{CO}_{2}$, Nature, 363, 439-443, https://doi.org/10.1038/363439a0, 1993.

Francey, R. J. and Tans, P. P.: Latitudinal variation in oxygen-18 of atmospheric $\mathrm{CO}_{2}$, Nature, 327, 495-497, https://doi.org/10.1038/327495a0, 1987.

Geldern, R. van, Nowak, M. E., Zimmer, M., Szizybalski, A., Myrttinen, A., Barth, J. A. C., and Jost, H.-J.: Field-Based Stable Isotope Analysis of Carbon Dioxide by Mid-Infrared Laser Spectroscopy for Carbon Capture and Storage Monitoring, Anal. Chem., 86, 12191-12198, https://doi.org/10.1021/ac5031732, 2014.

Gillon, J. and Yakir, D.: Influence of Carbonic Anhydrase Activity in Terrestrial Vegetation on the ${ }^{18} \mathrm{O}$ Content of Atmospheric $\mathrm{CO}_{2}$, Science, 291, 2584-2587, https://doi.org/10.1126/science.1056374, 2001.

Gilmour, K. M.: Perspectives on carbonic anhydrase, Comp. Biochem. Phys. A, 157, 193-197, https://doi.org/10.1016/j.cbpa.2010.06.161, 2010.

Hewett-Emmett, D. and Tashian, R. E.: Functional Diversity, Conservation, and Convergence in the Evolution of the $\alpha-, \beta-$, and $\gamma$-Carbonic Anhydrase Gene Families, Mol. Phylogenet. Evol., 5, 50-77, https://doi.org/10.1006/mpev.1996.0006, 1996.

Hopkinson, B. M., Meile, C., and Shen, C.: Quantification of Extracellular Carbonic Anhydrase Activity in Two Marine Diatoms and Investigation of Its Role, Plant Physiol., 162, 1142-1152, https://doi.org/10.1104/pp.113.217737, 2013.

Hsieh, J. C., Chadwick, O. A., Kelly, E. F., and Savin, S. M.: Oxygen isotopic composition of soil water: Quantifying evaporation and transpiration, Geoderma, 82, 269-293, https://doi.org/10.1016/S0016-7061(97)00105-5, 1998a.

Hsieh, J. C. C., Savin, S. M., Kelly, E. F., and Chadwick, O. A.: Measurement of soil-water $\delta^{18} \mathrm{O}$ values by direct equilibration with $\mathrm{CO}_{2}$, Geoderma, 82, 255-268, https://doi.org/10.1016/S0016-7061(97)00104-3, 1998b.

Jarvis, P., Rey, A., Petsikos, C., Wingate, L., Rayment, M., Pereira, J., Banza, J., David, J., Miglietta, F., Borghetti, M., Manca, G., and Valentini, R.: Drying and wetting of Mediterranean soils stimulates decomposition and carbon dioxide emission: The "Birch effect", Tree Physiol., 27, 929-940, https://doi.org/10.1093/treephys/27.7.929, 2007.

Kapiluto, Y., Yakir, D., Tans, P., and Berkowitz, B.: Experimental and numerical studies of the ${ }^{18} \mathrm{O}$ exchange between $\mathrm{CO}_{2}$ and water in the atmosphere-soil invasion flux, Geochim. Cosmochim. Ac., 71, 2657-2671, https://doi.org/10.1016/j.gca.2007.03.016, 2007.

Kaur, S., Mishra, M. N., and Tripathi, A. K.: Regulation of expression and biochemical characterization of a $\beta$-class carbonic anhydrase from the plant growth-promoting rhizobacterium, Azospirillum brasilense Sp7, FEMS Microbiol. Lett., 299, 149_ 158, https://doi.org/10.1111/j.1574-6968.2009.01736.x, 2009.

Lebeau, M. and Konrad, J.-M.: A new capillary and thin film flow model for predicting the hydraulic conductivity of unsaturated porous media, Water Resour. Res., 46, W12554, https://doi.org/10.1029/2010WR009092, 2010.

Li, W., Yu, L.-j., Yuan, D.-X., Wu, Y., and Zeng, X.-D.: A study of the activity and ecological significance of carbonic 
anhydrase from soil and its microbes from different karst ecosystems of Southwest China, Plant Soil, 272, 133-141, https://doi.org/10.1007/s11104-004-4335-9, 2005a.

Li, W., Yu, L.-j., He, Q.-F., Wu, Y., Yuan, D.-X., and Cao, J.-H.: Effects of microbes and their carbonic anhydrase on $\mathrm{Ca}^{2+}$ and $\mathrm{Mg}^{2+}$ migration in column-built leached soillimestone karst systems, Appl. Soil Ecol., 29, 274-281, https://doi.org/10.1016/j.apsoil.2004.12.001, 2005 b.

Lin, Y. and Horita, J.: An experimental study on isotope fractionation in a mesoporous silica-water system with implications for vadose-zone hydrology, Geochim. Cosmochim. Ac., 184, 257271, https://doi.org/10.1016/j.gca.2016.04.029, 2016.

Linn, D. M. and Doran, J. W.: Effect of Water-Filled Pore Space on Carbon Dioxide and Nitrous Oxide Production in Tilled and Nontilled Soils, Soil Sci. Soc. Am. J., 48, , 1267-1272, https://doi.org/10.2136/sssaj1984.03615995004800060013x, 1984.

Lis, G., Wassenaar, L. I., and Hendry, M. J.: High-Precision Laser Spectroscopy $\mathrm{D} / \mathrm{H}$ and ${ }^{18} \mathrm{O} /{ }^{16} \mathrm{O}$ Measurements of Microliter Natural Water Samples, Anal. Chem., 80, 287-293, https://doi.org/10.1021/ac701716q, 2008.

Massman, W. J.: A review of the molecular diffusivities of $\mathrm{H}_{2} \mathrm{O}$, $\mathrm{CO}_{2}, \mathrm{CH}_{4}, \mathrm{CO}, \mathrm{O}_{3}, \mathrm{SO}_{2}, \mathrm{NH}_{3}, \mathrm{~N}_{2} \mathrm{O}, \mathrm{NO}$, and $\mathrm{NO}_{2}$ in air, $\mathrm{O}_{2}$ and $\mathrm{N}_{2}$ near STP, Atmos. Enviro., 32, 1111-1127, https://doi.org/10.1016/S1352-2310(97)00391-9, 1998.

Merlin, C., Masters, M., McAteer, S., and Coulson, A.: Why Is Carbonic Anhydrase Essential to Escherichia coli?, J. Bacteriol., 185, 6415-6424, https://doi.org/10.1128/JB.185.21.64156424.2003, 2003

Miller, J. B., Yakir, D., White, J. W. C., and Tans, P. P.: Measurement of ${ }^{18} \mathrm{O} /{ }^{16} \mathrm{O}$ in the soil-atmosphere $\mathrm{CO}_{2}$ flux, Global Biogeochem. Cy., 13, 761-774, https://doi.org/10.1029/1999GB900028, 1999.

Mills, G. A. and Urey, H. C.: The Kinetics of Isotopic Exchange between Carbon Dioxide, Bicarbonate Ion, Carbonate Ion and Water1, J. Am. Chem. Soc., 62, 1019-1026, https://doi.org/10.1021/ja01862a010, 1940.

Moldrup, P., Olesen, T., Komatsu, T., Yoshikawa, S., Schjønning, P., and Rolston, D.: Modeling diffusion and reaction in soils: X. A unifying model for solute and gas diffusivity in unsaturated soil, Soil Sci., 168, 321-337, 2003.

Oerter, E., Finstad, K., Schaefer, J., Goldsmith, G. R., Dawson, T., and Amundson, R.: Oxygen isotope fractionation effects in soil water via interaction with cations $(\mathrm{Mg}, \mathrm{Ca}, \mathrm{K}, \mathrm{Na})$ adsorbed to phyllosilicate clay minerals, J. Hydrol., 515, 1-9, https://doi.org/10.1016/j.jhydrol.2014.04.029, 2014.

Ogée, J., Peylin, P., Cuntz, M., Bariac, T., Brunet, Y., Berbigier, P., Richard, P., and Ciais, P.: Partitioning net ecosystem carbon exchange into net assimilation and respiration with canopyscale isotopic measurements: An error propagation analysis with 13CO2 and CO18O data, Global Biogeochem. Cy., 18, GB2019, https://doi.org/10.1029/2003GB002166, 2004.

Ogée, J., Sauze, J., Kesselmeier, J., Genty, B., Van Diest, H., Launois, T., and Wingate, L.: A new mechanistic framework to predict OCS fluxes from soils, Biogeosciences, 13, 2221-2240, https://doi.org/10.5194/bg-13-2221-2016, 2016.

Orlowski, N., Frede, H.-G., Brüggemann, N., and Breuer, L.: Validation and application of a cryogenic vacuum extraction system for soil and plant water extraction for isotope analysis, J. Sens.
Sens. Syst., 2, 179-193, https://doi.org/10.5194/jsss-2-179-2013, 2013.

Orlowski, N., Breuer, L., and McDonnell, J. J.: Critical issues with cryogenic extraction of soil water for stable isotope analysis, Ecohydrology, 9, 1-5, https://doi.org/10.1002/eco.1722, 2016a.

Orlowski, N., Pratt, D. L., and McDonnell, J. J.: Intercomparison of soil pore water extraction methods for stable isotope analysis, Hydrol. Process., 30, 3434-3449, https://doi.org/10.1002/hyp.10870, 2016 b.

R Core Team: R: A Language and Environment for Statistical Computing, R Foundation for Statistical Computing, Vienna, Austria, vailable at: https://www.R-project.org/, last access: 17 April 2017.

Riley, W. J.: A modeling study of the impact of the $\delta^{18} \mathrm{O}$ value of near-surface soil water on the $\delta^{18} \mathrm{O}$ value of the soilsurface $\mathrm{CO}_{2}$ flux, Geochim. Cosmochim. Ac., 69, 1939-1946, https://doi.org/10.1016/j.gca.2004.10.021, 2005.

Rizzo, A. L., Jost, H.-J., Caracausi, A., Paonita, A., Liotta, M., and Martelli, M.: Real-time measurements of the concentration and isotope composition of atmospheric and volcanic $\mathrm{CO} 2$ at Mount Etna (Italy), Geophys. Res. Lett., 41, 2382-2389, https://doi.org/10.1002/2014GL059722, 2014.

Savin, S. M. and Epstein, S.: The oxygen and hydrogen isotope geochemistry of clay minerals, Geochim. Cosmochim. Ac., 34, 2542, https://doi.org/10.1016/0016-7037(70)90149-3, 1970.

Seibt, U., Wingate, L., Lloyd, J., and Berry, J. A.: Diurnally variable $\delta^{18} \mathrm{O}$ signatures of soil $\mathrm{CO}_{2}$ fluxes indicate carbonic anhydrase activity in a forest soil, J. Geophys. Res., 111, G04005, https://doi.org/10.1029/2006JG000177, 2006.

Smith, K. S. and Ferry, J. G.: Prokaryotic carbonic anhydrases, FEMS Microbiol. Rev., 24, 335-366, https://doi.org/10.1111/j.1574-6976.2000.tb00546.x, 2000.

Smith, K. S., Jakubzick, C., Whittam, T. S., and Ferry, J. G.: Carbonic anhydrase is an ancient enzyme widespread in prokaryotes, P. Natl. Acad. Sci. USA, 96, 15184-15189, https://doi.org/10.1073/pnas.96.26.15184, 1999.

Sprenger, M., Herbstritt, B., and Weiler, M.: Established methods and new opportunities for pore water stable isotope analysis, Hydrol. Process., 29, 5174-5192, https://doi.org/10.1002/hyp.10643, 2015.

Stern, L. A., Amundson, R., and Baisden, W. T.: Influence of soils on oxygen isotope ratio of atmospheric $\mathrm{CO}_{2}$, Global Biogeochem. Cy., 15, 753-759, https://doi.org/10.1029/2000GB001373, 2001.

Tans, P. P.: Oxygen isotopic equilibrium between carbon dioxide and water in soils, Tellus B, 50, 163-178, https://doi.org/10.3402/tellusb.v50i2.16094, 1998.

Tokunaga, T. K.: Physicochemical controls on adsorbed water film thickness in unsaturated geological media, Water Resour. Res., 47, W08514, https://doi.org/10.1029/2011WR010676, 2011.

Tu, C., Wynns, G. C., McMurray, R. E., and Silverman, D. N.: $\mathrm{CO}_{2}$ kinetics in red cell suspensions measured by ${ }^{18} \mathrm{O}$ exchange, J. Biol. Chem., 253, 8178-8184, 1978.

Tuller, M. and Or, D.: Hydraulic conductivity of variably saturated porous media: Film and corner flow in angular pore space, Water Resour. Res., 37, 1257-1276, https://doi.org/10.1029/2000WR900328, 2001.

Uchikawa, J. and Zeebe, R. E.: The effect of carbonic anhydrase on the kinetics and equilibrium of the oxygen isotope exchange 
in the $\mathrm{CO}_{2}-\mathrm{H}_{2} \mathrm{O}$ system: Implications for $\delta^{18} \mathrm{O}$ vital effects in biogenic carbonates, Geochim. Cosmochim. Ac., 95, 15-34, https://doi.org/10.1016/j.gca.2012.07.022, 2012.

Weiss, R. F.: Carbon dioxide in water and seawater: The solubility of a non-ideal gas, Mar. Chem., 2, 203-215, https://doi.org/10.1016/0304-4203(74)90015-2, 1974.

Welp, L. R., Keeling, R. F., Meijer, H. A. J., Bollenbacher, A. F., Piper, S. C., Yoshimura, K., Francey, R. J., Allison, C. E., and Wahlen, M.: Interannual variability in the oxygen isotopes of atmospheric $\mathrm{CO}_{2}$ driven by El Nino, Nature, 477, 579-582, https://doi.org/10.1038/nature10421, 2011.

Wen, X.-F., Meng, Y., Zhang, X.-Y., Sun, X.-M., and Lee, X.: Evaluating calibration strategies for isotope ratio infrared spectroscopy for atmospheric ${ }^{13} \mathrm{CO}_{2} /{ }^{12} \mathrm{CO}_{2}$ measurement, Atmos. Meas. Tech., 6, 1491-1501, https://doi.org/10.5194/amt-6-14912013, 2013.

Werle, P.: Accuracy and precision of laser spectrometers for trace gas sensing in the presence of optical fringes and atmospheric turbulence, Appl. Phys. B-Photo., 102, 313-329, https://doi.org/10.1007/s00340-010-4165-9, 2010.

Wilbur, K. M. and Anderson, N. G.: Electrometric and Colorimetric Determination of Carbonic Anhydrase, J. Biol. Chem., 176, 147$154,1948$.
Wingate, L., Seibt, U., Maseyk, K., Ogée, J., Almeida, P., Yakir, D., Pereira, J. S., and Mencuccini, M.: Evaporation and carbonic anhydrase activity recorded in oxygen isotope signatures of net $\mathrm{CO}_{2}$ fluxes from a Mediterranean soil, Glob. Change Biol., 14, 2178-2193, https://doi.org/10.1111/j.13652486.2008.01635.x, 2008.

Wingate, L., Ogée, J., Cuntz, M., Genty, B., Reiter, I., Seibt, U., Yakir, D., Maseyk, K., Pendall, E. G., Barbour, M. M., Mortazavi, B., Burlett, R., Peylin, P., Miller, J., Mencuccini, M., Shim, J. H., Hunt, J., and Grace, J.: The impact of soil microorganisms on the global budget of $\delta 180$ in atmospheric $\mathrm{CO}_{2}$, P. Natl. Acad. Sci. USA, 106, 22411-22415, https://doi.org/10.1073/pnas.0905210106, 2009.

Wingate, L., Ogée, J., Burlett, R., and Bosc, A.: Strong seasonal disequilibrium measured between the oxygen isotope signals of leaf and soil $\mathrm{CO}_{2}$ exchange, Glob. Change Biol., 16, 3048-3064, https://doi.org/10.1111/j.1365-2486.2010.02186.x, 2010.

Xu, Y., Feng, L., Jeffrey, P. D., Shi, Y., and Morel, F. M. M.: Structure and metal exchange in the cadmium carbonic anhydrase of marine diatoms, Nature, 452, 56-61, https://doi.org/10.1038/nature06636, 2008.

Yakir, D. and Wang, X.-F.: Fluxes of $\mathrm{CO}_{2}$ and water between terrestrial vegetation and the atmosphere estimated from isotope measurements, Nature, 380, 515-517, https://doi.org/10.1038/380515a0, 1996. 